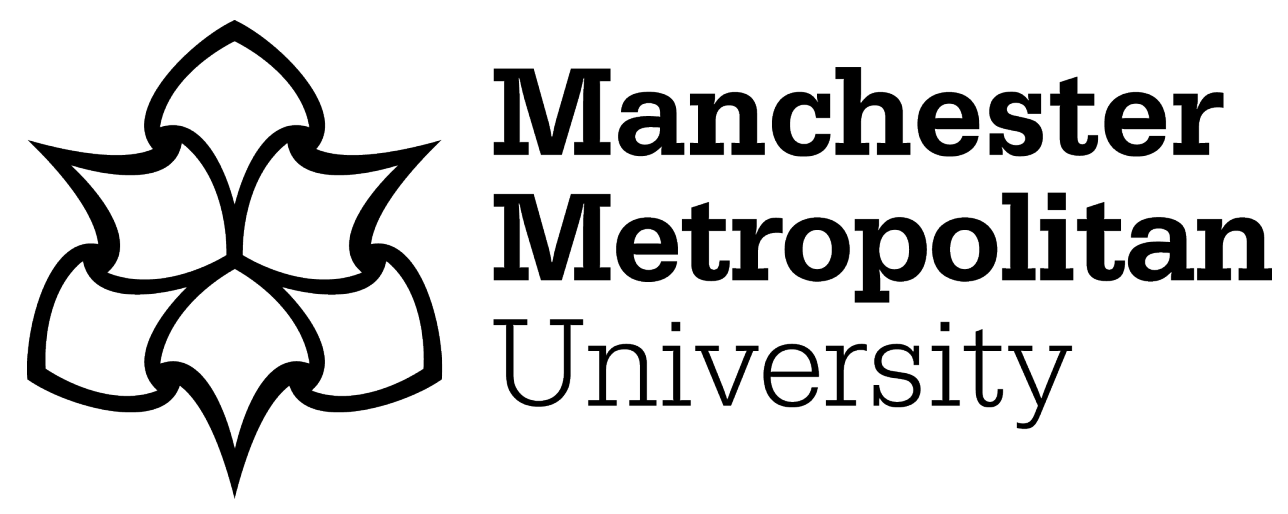

Giovanis, Eleftherios (2015) The effect of Smog-Ozone warnings and a vanpool program on traffic volume in york county of south carolina. Environment and Planning B: Planning and Design, 42 (2). pp. 195-220. ISSN 0265-8135

Downloaded from: https://e-space.mmu.ac.uk/620961/

Version: Accepted Version

Publisher: Sage

DOI: https://doi.org/10.1068/b130018p

Please cite the published version 


\title{
The effect of smog-ozone warnings and vanpool program on traffic volume in York County of South Carolina
}

\begin{abstract}
Ground-level ozone is a critical criteria pollutant that is significantly generated by transportation patterns. We study the effect of smog-ozone warnings, triggered by EPA, on traffic volume in York County of South Carolina during period 2006-2010. In addition- the subperiods 2006-2007 and 2008-2010, where the ozone smog alert thresholds are 0.080 parts per million (ppm) and $0.075 \mathrm{ppm}$ respectively, are examined. The approach followed in this paper is a differences-in-difference (DID) regression. Additionally, a Regression Discontinuity Design (RDD) into a DID framework is applied. We find a negative and significant decrease in weekday peak-hour traffic volume in the treatment group during period 2008-2010.
\end{abstract}

Keywords: Air Quality; Differences-in-Differences; Ground Level Ozone; Regression Discontinuity, Smog Alerts; Traffic

\section{Introduction}




\subsection{Background}

The United Nations estimated that over 600 million people in urban areas worldwide in 1980s were exposed to dangerous levels of traffic-generated air pollutants (United Nations, 1989; Cacciola et al., 2002). This is still an issue, especially in the countries of Africa and Asia, which together will account for 86 per cent of all growth in the world's urban population over the next four decades (United Nations, 2012).

A number of epidemiological studies support the view that exposure to traffic-related pollutants is associated with a broad spectrum of adverse short-term respiratory effects in vulnerable individuals. People in Japan living close to main roads with heavy traffic suffered more respiratory symptoms and allergies than those living further away (Yokoyama et al. 1985; Ishizaki et al. 1987; Ono et al. 1990; Shima et al. 2002; Shima et al. 2003; Anderson et al. 2005; Ostro et al. 2006; Analitis et al. 2006). Similar studies carried out in other countries, like UK, USA and in the Netherlands (Edwards et al. 1994; Oosterlee et al. 1996; Van Vliet et al. 1997; McConnell et al. 2006) reported increased respiratory symptoms and reduced lung function in those children living in close proximity of roads with high traffic intensity, which is positively correlated with the levels of particulate matter in the atmosphere.

Charlotte Area Transit System (CATS), which is an area-region of North and South Carolina sponsors a vanpool program. The aim of vanpool programs is to allow commuters to ride together in a van, particularly in areas where public transportation is not provided. One rider is the designated driver, and CATS covers the cost of insurance, fuel, maintenance, and a Guaranteed Ride Home program. The vanpool program currently offers minivans, for four to seven passengers, and vans, for up to 15 passengers at a cost. More precisely, the cost of commuting is shared with other members of the vanpool. The vanpool fare structure is designed 
to cover operating costs, including fuel, maintenance, mileage and other administrative expenses, as insurance and staff time are supplementary costs covered in the fare structure. In addition the fare depends on van type and the round trips miles per day.

By offering a guaranteed ride home, as the vanpool program, allows employers to remove a major barrier to alternative commute methods-employee fears of being "stranded" at work due to unforeseen circumstances. This type of program provides employees who commute via transit, carpool, or vanpool with transportation home in the event of a personal emergency or unscheduled overtime. The benefits can include a wide variety of commuting choices (carpool, vanpool and public transit), choices that make commuting less stressful and less costly for employees.

Additionally, the current economic downturn has resulted in a disproportionate loss of jobs in rural communities, necessitating longer work commutes for some rural residents. In rural communities where public transportation is limited, these developments present challenges to accessing work.

\subsection{Purpose of Study}

The purpose of this paper is the smog warnings' effects on traffic volume before and after the change of smog alert threshold triggered by Environmental Protection Agency (EPA). ${ }^{1}$ During the period of 2006-2007 the threshold for warning issue was $0.080 \mathrm{ppm}$, this threshold was reduced to $0.075 \mathrm{ppm}$ for the period 2008-2010. The aim and contribution of this study is twofold. Firstly, to estimate whether there is any difference in the traffic volumes between the treatment county (York) and the control county (Spartanburg) in North Carolina State. The second research question is whether the traffic volume has been increased or decreased after the change of the threshold. This is done by applying differences-in-differences (DID)

\footnotetext{
${ }^{1}$ However the study of the vanpool program in York County is not possible because of the traffic data unavailability since its beginning.
} 
regressions. Additionally, regression discontinuity (RD) estimations into a Difference-inDifferences (DID) framework (Cutter and Neidell, 2009) are applied. The use of DID in that case is very useful for the following reasons: The simplest set up is one where outcomes are observed for two groups for two time periods. One of the groups is exposed to a treatmentwhich is the vanpool program in York county- while the second group-control- is not exposed to the treatment during either period, while in both groups a smog alert system is available. In the case where the same units within a group are observed in each time period, the average gain in the second (control) group is subtracted from the average gain in the first (treatment) group. This removes biases in second period comparisons between the treatment and control group that could be the result from permanent differences between those groups, as well as biases from comparisons over time in the treatment group that could be the result of trends. Similarly, the regression discontinuity design into a Difference-in- Differences framework allows us to examine the traffic volume when passing a certain threshold induces a change in the independent variable of interest, which is the smog alert. The idea is that observations just below and just above the threshold are fairly comparable (Imbens and Lemieux, 2008; Lee and Lemieux).

The structure of the paper is as follows: In section 2 the literature review of previous researches is provided. Section 3 reviews the methodology of the models used in this study. Section 4 presents the data, and the research sample used in the estimations, while in section 5 the empirical findings are reported. In the last section the general conclusions of the empirical findings are presented. Generally, using daily data the traffic volume is decreased at 31.909 per cent in York County when the sample is restricted to peak hours of the day and MondaysFridays. Similarly, using hourly data a significant negative percentage of traffic volume equal to 29.282 per cent, using the peak hours of the day, is reported during Mondays to Fridays. 


\section{Literature Review}

2.1 Air pollution and public health

The association between mortality rate and particulate air pollution has long been studied. Dockery et al. (1993) related excess daily mortality from cancer and cardiopulmonary disease to several air pollutants, especially fine particulate matter $\mathrm{PM}_{2.5}$ in their prospective cohort study, which is Watertown in Massachusetts, Harriman in Tennessee, St. Louis in Missouri, Steubenville in Ohio, Portage in Wisconsin and Topeka in Kansas. Since then, many other epidemiological studies on the adverse effects of air pollutants have been carried out, ranging from variations in physiological functions and subclinical symptoms like heart rate variability and peak expiratory flow rate to manifest clinical diseases as asthma, stroke, lung cancer, and leukaemia among others, premature births and deaths (Delfino et al., 1998; Naeher et al., 1999; Laden et al., 2000; Suresh et al., 2000; Janssen et al., 2002;; Wilhelm and Ritz, 2003; O’Neill et al., 2004; Preutthipan et al., 2004). More specifically, Delfino et al., (1998) report that the emergency rooms were 21.8 per cent higher than the average for a mean increase of $44 \mathrm{O}_{3}$ part per billion (ppb), while an increase in $\mathrm{PM}_{2.5}$ from coal combustion sources accounted for a $1.1 \%$ increase in daily mortality (Laden et al., 2000).

On the other hand Currie and Neidell (2005) using the California Birth Cohort files and the California Ambient Air Quality Data during period 1989-2000 propose an identification strategy using individual level data and exploiting within-zip code-month variation in pollution levels and creating measures of pollution at the zip code-week level and controlling for individual differences between mothers that may be associated with variation in birth outcomes. The authors find little average effect of prenatal pollution exposure on the probability of low birth weight, short gestation and fetal death after including the mother's zip code in the model. 
However, the authors find that living in a very high-pollution area is associated with a higher risk of fetal death, suggesting that pollution may be harmful above a certain threshold level.

Chay and Greenstone (2003a) examined the air quality improvements induced by the Clean Air Act Amendments (CAAAs) of 1970 to estimate the impact of particulates pollution on infant mortality during period 1971-1972. Their strategy has some attractive features, as the fact that federally-mandated regulatory pressure is orthogonal to county-level changes in infant mortality rates, except through its impact on air pollution. Therefore, nonattainment status may be a valid instrument. Also the authors use regulation-induced changes that occurred during an economic expansion period 1971-1972; thus, any potential biases due to economic shocks are likely to be mitigated. The federal air pollution regulations are associated with sharp reductions in both total suspended particulates (TSPs) pollution and infant mortality rates in the first year that the 1970 Clean Air Act Amendments were in force. The authors find that a one per cent decline in TSP results in a 0.5 per cent decline in the infant mortality rate. Chay and Greenstone (2003b) used substantial differences in air pollution reductions across sites to estimate the impact of TSPs on infant mortality. The authors establish that most of the 1980-82 declining in TSPs was attributable to the differential impacts of the 1981-82 recession across counties. The authors find that a one percent reduction in TSPs results in a 0.35 percent decline in the infant mortality rate at the county level. Chay et al. (2003) examined the adult health impact of a oneyear reduction in TSPs air pollution induced by the Clean Air Act of 1970. While the authors find that regulatory intensity is associated with large TSPs reductions, it has little systematic association with reductions in either adult or elderly mortality, implying that the regulationinduced reduction in TSPs is not associated with improvements in adult mortality.

2.2 The effect of information system on human behaviour change 
The majority of the research studies has examined the effects of ozone forecasts or ozone action days on traffic volume; however the impact of vanpool programs related to ozone forecasts has not been explored yet. EPA's purpose (Air Quality Management Work Group, 2005) of announcing emissions reports and ozone forecasts is to provide a motivation to people and firms to take actions in order to improve air. For example, Konar and Cohen (1997) found that firms, which had significant, negative abnormal returns upon the public announcement of their toxic release inventory (TRI) emissions in 1989, subsequently reduced their TRI emissions more than other firms in their industry. In addition, the authors show that repeated provision of information allows investors to benchmark a firm's environmental performance and make comparisons of performance over time as well as across firms. Therefore toxic release inventory enables stockholders to react to the changes in a firm's environmental performance over time. Further evidence is presented by Hamilton (1995) in an analysis of the dollar value of abnormal returns on the day of toxic release inventory disclosure. After controlling for size of firm, he found a positive correlation between the number of existing Superfund sites (already known to the public) and abnormal returns.

A different approach shows that the transportation improvement program in Lancaster and Berks counties in Pennsylvania significantly improved the air quality. (Reading Metropolitan Planning Organization and Pennsylvania Department of Transportation, 2010; Lancaster County Planning Commission Staff for the Lancaster County Transportation Coordinating Committee, 2012). The FFY 2011-2014 Transportation Improvement Program includes highway, bridge, and public transit projects as well as non-traditional bicycle and pedestrian projects. Similarly, the 2035 Long-Range Regional Transportation Plan Update sets priorities for spending federal funds on transportation projects. More specifically, the Long-Range Regional Transportation Plan Update covers all modes of transport including automobile, 
transit, bicycle, pedestrian railroad, freight and intermodal movements. The studies use a set of computer programs and databases to estimate vehicle miles of travel and operating speeds, and to subsequently calculate emission factors and total emissions. The programs calculate the impact of regional population and employment growth, transportation projects, and travel diversions on total emission estimates.

Most researches examine generally the ozone advisories programs effects on traffic volumes and not the vanpool or carpool programs. Several Air Quality Management Districts (AQMDs) in California have implemented ozone outreach action programs, called "Spare the Air" (STA), to elicit voluntary reductions in ozone-producing activities. STAs are issued when ozone levels are predicted to exceed a particular threshold. Schreffler (2003) focused on "Spare the Air" advisory program by conducting a small telephone survey in the Bay Area that requested daily travel activities, and found a statistically significant 4.8 percent reduction in trips when smog alerts implemented. This resulted in an emission reduction of 1.04 tons of ozone precursors, or 0.74 tons after controlling for trip reduction on non-Spare the Air days and he estimated that drivers, on average, took 0.45 more trips on non-STA days. So it could be said that Spare the Air resulted in 0.45 fewer trips when applied to the population of drivers or 4.68 tons of ozone precursors.

Cummings and Walker (2000) examined a similar voluntary program in the Atlanta of Georgia metropolitan area on hourly traffic volumes and found statistically insignificant effects. More specifically, the authors control for traffic recorders, time effects, as months, days and holidays, they control for weather conditions, as if the day was sunny, or if there was snowfall or rainfall. Lastly whether a day is an action ozone day or not is considered in the analysis. However, whether a day is action ozone day or not has no significant different effects on traffic volume. 
Welch et al. (2005) examined the impact of ozone advisories on hourly train ridership in Chicago (Illinois) during period 2002-2003 controlling for weather conditions, days, months and holidays. The findings suggests that while the overall effect of ozone action days on ridership is not significant, there are statistically significant changes in hourly ridership patterns. More specifically, the authors found increases during peak commuting periods and decreases during non-peak hours. Cutter and Neidell (2009) examined the effects of "Spare the Air" advisory program in San Francisco Bay Area. Cutter and Neidell (2009) use as treatment and control groups the San Francisco Bay Area and the metropolitan region of Los Angeles respectively. The authors estimate a regression discontinuity approach using a sample of observations within 0.02 and $0.01 \mathrm{ppm}$ and they show a statistically significant drop in size to over 2,300 and 2,000 vehicles respectively in the San Francisco Bay Area. Friedman et al. (2001) examined the changes in transportation choices and the effects on asthma hospitalisations during the Olympic Games in Atlanta of 1996. Atlanta's strategy included the development and use of an integrated 24-hour-aday public transportation system, the addition of 1,000 buses for park and ride services, altered downtown delivery schedules, and public warnings of potential traffic and air quality problems among others. The authors compare the 17 days of the Olympic Games, during $19^{\text {th }}$ of July to $4^{\text {th }}$ of August 1996, with a baseline period of four weeks before and four weeks after the Olympic Games without using a control group. The authors found that the number of asthma emergency care visits and hospitalisations decreased from 4.23 events per day during the baseline period to 2.47 events per day during the Olympic period, a $41.6 \%$ overall decrease. Additionally, this reduction was even stronger during the critical morning period. Lu et al. (2004) collected comprehensive travel data of a random sample of the general population and of individuals who said they responded to the Spare the Air (STA) message during two summer ozone seasons in Sacramento. The authors studied the travel behaviour of the same individuals on both Spare the Air and regular- non- 
Spare the Air - summer days and of individuals located in STA and non-STA areas. They found a statistically significant difference between self-reported vehicle trip reductions and measured vehicle trip changes due to Spare the Air programs among STA participants.

Sexton (2010) examines the extent of the effects to which free transit fares and appeals for car trip avoidance reduce car pollution on smoggy days. Indirect effects associated with Spare the Air alerts, however, may lead to increased demand for car trips and less demand for transit. For instance, Spare the Air alerts may function as warnings about air pollution, triggering transit passengers to substitute to car trips in order to minimize exposure to bad air Sexton (2010) using a regression discontinuity approach finds that public appeals are shown to increase carpooling but not transit ridership, while on the other hand free fares increase transit ridership but not carpooling.

A different study by Bento et al. (2010) examines the effect of the Clean Air Stickers program in California on high-occupancy vehicle (HOV) lane congestion, mainline congestion, and hybrid vehicle registration. More specifically, the Clean Air Stickers program began on August 10, 2005 in California and for a small fee of $\$ 8$ dollars, owners of hybrid vehicles achieving 45 miles-per-gallon (mpg) or better were able to apply for a special sticker that allowed them access to HOV lanes regardless of the number of occupants in the vehicle. The stated goal of the specific program's policy was to stimulate the demand for highly fuel-efficient vehicles, particularly of ultra-low-emission vehicles. However, the authors using a regression discontinuity design found no evidence that this policy stimulated registration of hybrid vehicles, and as a consequence, greenhouse gas emissions may have actually increased.

\section{Data}


The data for forecasting ozone concentrations have been retrieved by South Carolina Department of Health and Environmental Control (http://www.scdhec.gov). Traffic volume data come directly from Traffic Polling and Analysis System of South Carolina (http://www.scdot.org). It should be noted that the data sample refers to all available traffic monitoring sites. The weather and meteorological data have been found on TuTiempo.net, which contains a detailed database for all monitoring stations in South Carolina. The remained variables, personal income per capita and unemployment rate have been retrieved by the Federal Reserve Bank of St. Louis (http://research.stlouisfed.org) and Bureau of Economic Analysis (http://www.bea.gov) and the income reference year is 2005. Additionally, population can be found on the Census Bureau of USA. The period used in the study is 2006-2010. Table 1 presents the scale developed by Environmental Protection Agency that relates shorter and longer-term exposure to the ambient ozone concentrations, in parts per billion (ppb), to health risk.

Ozone is a gas composed of three oxygen atoms. It is not usually emitted directly into the air, but is created at ground-level by a chemical reaction between oxides of nitrogen (NOx) and volatile organic compounds (VOC). Because of this process, ozone levels vary considerably both across and within days (Environmental Protection Agency, 2006). Ground level ozone can harm peoples' health. People with lung disease, children, older adults, and people who are active outdoors may be particularly sensitive to ozone.

The air quality forecasts are provided as part of the air quality index by EPA, which sets the National Ambient Air Quality Standards (NAAQS). This index ranges from 0 to 500. The purpose of the Air Quality Index (AQI) is to help people understand what local air quality means to their health. To make it easier to understand, the Air Quality Index is divided into six levels of health concern: and addresses the ranges of ozone that are represented by the AQI categories, 
such as "good," "moderate," "unhealthy for sensitive groups," "unhealthy", "very unhealthy" and "hazardous" based on table 1 (Environmental Protection Agency, 2006).

Table 1. Ozone AQI categories

\begin{tabular}{|c|c|c|c|c|}
\hline $\begin{array}{l}\text { Ozone AQI } \\
\text { value }\end{array}$ & $\begin{array}{l}1997 \\
\text { 8-hour } \\
\text { (ppb) }\end{array}$ & $\begin{array}{c}2008 \\
\text { 8-hour } \\
\text { (ppb) }\end{array}$ & AQI category & Ozone Health information \\
\hline $0-50$ & $0-64$ & $0-59$ & Good & None \\
\hline $51-100$ & $65-84$ & $60-75$ & Moderate & $\begin{array}{l}\text { Unusually sensitive people should } \\
\text { consider reducing prolonged or heavy } \\
\text { exertion outdoors }\end{array}$ \\
\hline $101-150$ & $85-104$ & $76-95$ & $\begin{array}{c}\text { Unhealthy for } \\
\text { sensitive groups }\end{array}$ & $\begin{array}{c}\text { Active children and adults, and people } \\
\text { with lung disease, such as asthma, should } \\
\text { reduce prolonged or heavy exertion } \\
\text { outdoors. }\end{array}$ \\
\hline $151-200$ & $105-124$ & $96-115$ & Unhealthy & $\begin{array}{c}\text { Active children and adults, and people } \\
\text { with lung disease, such as asthma, should } \\
\text { avoid prolonged or heavy exertion } \\
\text { outdoors. Everyone else, especially } \\
\text { children, should reduce prolonged or } \\
\text { heavy exertion outdoors. }\end{array}$ \\
\hline $201-300$ & $125-374$ & $116-374$ & Very unhealthy & $\begin{array}{l}\text { Active children and adults, and people } \\
\text { with lung disease, such as asthma, should } \\
\text { avoid all outdoor exertion. Everyone } \\
\text { else, especially children, should avoid } \\
\text { prolonged or heavy exertion outdoors. }\end{array}$ \\
\hline $301-500$ & $>=375$ & $>=375$ & Hazardous & $\begin{array}{l}\text { Everyone should avoid all physical } \\
\text { activity outdoors }\end{array}$ \\
\hline
\end{tabular}

An Air Quality Index value of 100 generally corresponds to the national air quality standard for the pollutant, which is the level Environmental Protection Agency has set to protect public health. Air Quality Index values below 100 are generally thought of as satisfactory. When Air Quality Index values are above 100, air quality is considered to be unhealthy-at first for certain sensitive groups of people, then for everyone as Air Quality Index values get higher. Since 1997 the national standard was set up at 0.080 particles per million (ppm). This standard was reduced to $0.075 \mathrm{ppm}$ in 2008. Under the revised AQI, ozone levels above $0.075 \mathrm{ppm}$ would be classified as "unhealthy for sensitive groups"-known to many people as a "code orange" air quality day. When ozone is in this category, EPA recommends certain groups to adjust their activity levels to reduce their ozone exposure. These groups include children and adults who are active outdoors, people with asthma or other lung diseases and older adults. As it is shown 
in table 1 a ozone value of 75 particles per billion (ppb) or $0.75 \mathrm{ppm}$ corresponds at the value of 100 for Air Quality Index. More details about what each Air Quality Index scale means are reported in table 1. In addition, Air Quality Index is calculated based on a specific formula and the ozone concentrations. ${ }^{2}$

\section{Methodology}

Individuals have three main choices, to drive alone, to use public transit and to not take a trip. Additionally, there is a fourth choice, vanpooling, which mostly concerns York County, as there is a sponsored vanpool program from Charlotte Area Transit System and it is supported by Environmental Protection Agency. The vanpooling program is supported by Environmental Protection Agency since it might reduce traffic volumes and therefore improve the air quality.

The reason why Spartanburg County is taken as the control group is that it shares similar air quality and meteorological conditions population characteristics, and geographically Spartanburg and York counties are very close as map 1 shows $^{3}$. In addition Spartanburg county has a smog alert system, but not a vanpool program. Moreover, both counties are considered as non-attainment areas by EPA, which means that they do not meet the standards of clean air.

\section{(Enter Map 1)}

\footnotetext{
${ }^{2}$ The AQI conversion formula is defined as:

$A Q I=\frac{I_{H I}-I_{L O}}{B P_{H I}-B P_{L O}} \cdot\left(C_{03}-B P_{L O}\right)+I_{L O}$, where $\mathrm{AQI}$ is the air quality index, $\mathrm{I}_{\mathrm{LO}}$ and $\mathrm{I}_{\mathrm{HI}}$ are the index values at the lower and upper limit respectively of the $\mathrm{AQI}$ category, $\mathrm{BP}_{\mathrm{LO}}$ and $\mathrm{BP}_{\mathrm{HI}}$ are the break-point concentrations at lower and upper limit respectively of $\mathrm{AQI}$ category and $\mathrm{C}_{03}$ is the ozone concentration level.

${ }^{3}$ Cherokee county has been examined into analysis because it shares common borders with Spartanburg and York counties, as well as, with Charlotte area in North Carolina. However, the results do not change, therefore is not considered. The reason could be the great differences in economic and demographic characteristics. Additionally, the sample of Cherokee county is only 16 per cent of the total sample owned to the small number of traffic sites
} 
The first model is a differences-in-differences (DID) regression of the following form:

$y_{i j t}=\beta_{0}+\beta_{1}$ treat $_{i t}+\beta_{2}$ alert $_{j t}+\beta_{3}$ alert $_{j t} *$ treat $_{i t}+\beta_{4} y_{i t-1}+\gamma_{z}{ }^{\prime} W_{j t}+\delta_{z}{ }^{\prime} X_{j t}+\mu_{i}+l_{j}+\theta_{t}+\varepsilon_{i j t}$

, where variable $y$ is the traffic volume, subscript $i$ represents the traffic monitoring site, subscript $j$ denotes the ozone monitoring site and subscript $t$ indicates the date. Variable alert is a dummy variable obtaining value 1 if a smog alert is issued and 0 otherwise. Variable treat represents a dummy taking value 1 for the treatment group -where a vanpool program exists during the period examined- which contains the traffic monitors in York county, and 0 otherwise, which refers to traffic monitors in Spartanburg County. Vector $W$ includes meteorological variables as minimum, maximum and average temperature, humidity, precipitation and wind speed on the same day. Vector $X$ includes control variables for the county characteristics, as the population, the area, the unemployment rate and the personal income per capita on yearly basis. Moreover, one lag of the dependent variable is included into the model in order to account for any transitory shocks specific to a monitor or station, such as a highway construction project that lasts several days or even longer. This is followed also by Cummings and Walker (2000) and Welch et al. (2005), who include traffic or public transit lags from the previous hour, which in effect is comparing whether transportation choices changed within a day. Set $\mu_{\mathrm{i}}$ includes traffic monitoring dummy variables, set $l_{j}$ controls for counties, while set $\theta_{t}$ controls for hour, day of the week and month. Regression (1) takes place separately during the period 2006-2007 before the change of the threshold and 2008-2010 after the change. Finally, traffic monitoring sites are clustered in order to take robust standard errors.

The specification of the second differences-in-differences regression is the following: 


$$
\begin{aligned}
& y_{i j t}=\beta_{0}+\beta_{1} \text { alert }_{j t} * \text { treat }_{i j t}+\beta_{2} \text { post }_{t}+\beta_{3} \text { alert }_{j t} * \text { treat }_{i j t} * \text { post }_{t}+ \\
& \beta_{4} y_{i t-1}+\gamma_{z}{ }^{\prime} W_{j t}+\delta_{z}{ }^{\prime} X_{j t}+\mu_{i}+l_{j}+\theta_{t}+\varepsilon_{i j t}
\end{aligned}
$$

All the variables are defined as in relation (1), with the difference that variable alert_treat takes value 1 if a smog alert is issued in the treatment group and 0 otherwise. Furthermore, variable post is a dummy obtaining value 1 for the period 2008-2010, for threshold 0.075 ppm and 0 otherwise. Therefore the difference in specification (2) is that the whole period 20062010 is examined. The difference-in-difference approach is followed, including a control and a treatment group, in order to examine the effects of vanpool program on traffic volume. In addition, the difference-in-differences method removes any biases in second period comparisons between the treatment and control group that could be the result of permanent differences between those groups, as well as biases from comparisons over time in the treatment group that could be the result of changes in threshold. The differences-in-differences method can be implemented according to table 2 (Abadie, 2005; Angrist and Pischke, 2008):

Table 2. Differences-in-differences implementation

\begin{tabular}{|c|c|c|c|}
\hline $\mathrm{y}_{\text {it }}$ & $\mathrm{I}=1$ & $\mathrm{I}=2$ & Difference \\
\hline $\mathrm{T}=2$ & $\mathrm{y}_{12}$ & $\mathrm{y}_{22}$ & $\mathrm{y}_{12}-\mathrm{y}_{22}$ \\
\hline $\mathrm{T}=1$ & $\mathrm{y}_{11}$ & $\mathrm{y}_{21}$ & $\mathrm{y}_{11-} \mathrm{y}_{21}$ \\
\hline Change & $\mathrm{y}_{12} \mathrm{y}_{11}$ & $\mathrm{y}_{22}-\mathrm{y}_{21}$ & $\left.\mathrm{y}_{22}-\mathrm{y}_{21}\right)-\left(\mathrm{y}_{12}-\mathrm{y}_{11}\right)$ \\
\hline
\end{tabular}

Variable $y$ is the outcome-traffic volume in this case-, while $i$ and $t$ denote the group and time respectively. More specifically, the dummy variable alert_treat is a dummy variable indicating a smog alert is issued in the treatment group. So coefficient $\beta_{1}$ captures possible differences between the treatment and control groups prior to policy change (before the threshold change at $0.075 \mathrm{ppm}$ ) Variable post is a dummy variable for the second time period, 
taking value 1 for period 2008-2010. Therefore, coefficient $\beta_{2}$ captures aggregate factors that would cause changes in $y$ after the change in threshold prior to the policy change. The coefficient of interest in this case is $\beta_{3}$ which multiplies the interaction term alert_treat and post which is the same as a dummy variable equal to 1 for those observations where a smog alert is issued in the treatment group in the second period 2008-2010. The difference-in-differences estimate is shown in table 2 and it is $\beta_{3}=\left(y_{22-} y_{21}\right)-\left(y_{12-} y_{11}\right)$. In a similar fashion the differencein-differences estimator is defined for model (1).

The RD design was first introduced by Thistlethwaite and Campbell (1960) in their study of the impact of merit awards on future academic outcomes and since then it has been applied in various studies (Imbens and Lemieux, 2008; Lee and Lemieux, 2010). The reason why the differences-in-differences approach is expanded into a regression discontinuity design is to allow us to identify the causal effect of smog alerts on commuting behaviour, including at the same time a control and a treatment group. More specifically, since smog alerts are issued only when ozone is forecasted to exceed a particular threshold, traffic outcomes on days just above the threshold to outcomes on days just below the threshold are compared controlling for location, time and weather conditions. Any difference in outcomes can therefore be directly attributed to the smog alert day. However, it should be noticed that the differences-indifferences approach into a regression discontinuity framework might be not appropriate because the bandwidths examined, refer only to moderate air quality. More specifically, the individuals and/or the households might take more drastic measures when higher ozone forecasting values are reported. Additionally, there are various thresholds for different groups, as it can been seen in table 1, but the smog alert is issued for one threshold. For this reason the differences-in-differences are estimated in order to capture average behaviour across the whole sample. In addition, Regression Discontinuity Design is generally considered more closely related to random experiments than Differences-in-Differences method; thus the latter is 
preferred in this study. The Regression Discontinuity Design into a Differences-inDifferencesframework (Cutter and Neidell, 2009; Fremigacci, 2010) is as follows:

$$
\begin{aligned}
& y_{i j t}=\beta_{0}+\beta_{1} \text { alert }_{j t}+\beta_{2} \text { treat }_{i t}+\beta_{3} \text { alert }_{j t} * \text { treat }_{i t}+\beta_{4} y_{i t-1}+ \\
& g\left(\text { ozone }_{i, j, t}^{\mathrm{f}}\right)+\gamma_{z}{ }^{\prime} W_{j t}+\delta_{z}{ }^{\prime} X_{j t}+\mu_{i}+l_{j}+\theta_{t}+\varepsilon_{i j t}
\end{aligned}
$$

The variables are defined as in equation (1), while $g\left(\right.$ ozone $\left._{i, j, t}\right)$, is a function which relates the ozone forecasts with the actual ozone levels concentrations. Also an interaction term between the treatment and the forcing variable, which is ozone forecast, is added into the model in order to allow the regression function to differ on both sides of the cut off point ${ }^{4}$. For equation (2) is:

$$
\begin{aligned}
& y_{i j t}=\beta_{0}+\beta_{1} \text { alert }_{j t} * \text { treat }_{i j t}+\beta_{2} \text { post }_{t}+\beta_{3} \text { alert }_{j t} * \text { treat }_{i j t} * \text { post }_{t}+ \\
& \beta_{4} y_{i t-1}+g\left(\text { ozone }_{i, j, t}^{\mathrm{f}}\right)+\gamma_{z}{ }^{\prime} W_{j t}+\delta_{z}{ }^{\prime} X_{j t}+\mu_{i}+l_{j}+\theta_{t}+\varepsilon_{i j t}
\end{aligned}
$$

In the specification models (3)-(4), the causal impact of the transit system in treatment group is captured by the parameter $\beta_{3}$. More specifically, let $D_{i} \in\{0,1\}$ be a binary treatment variable indicating whether individuals are below $\left(D_{i}=0\right)$ or above $\left(D_{i}=1\right)$ the threshold. $Y_{i}^{0}, Y_{i}{ }^{1}$ are the individual potential outcomes and $Y_{i}{ }^{1}-Y_{i}^{0}$ is the individual treatment effect. In the sharp regression discontinuity design, the assignment $D_{i}$ is a deterministic function of one of the covariates $Z_{i}$ such that (Thistlethwaite and Campbell, 1960; Imbens and Lemieux, 2008; Cutter and Neidell, 2009; Fremigacci, 2010; Lee and Lemieux, 2010):

$D_{i}=1\left\{Z_{i} \geq c\right\}$

\footnotetext{
${ }^{4}$ As the results might be sensitive to the polynomial order, quadratic and cubic terms are examined as well. The results show no difference, as also the additional polynomial coefficients are insignificant.
} 
The forcing variable $Z_{i}$ in our case is the ozone forecast and the threshold $c$ we are interested in corresponds to the smog alert threshold. The average causal effect of the treatment at the discontinuity point is then given by:

$$
\begin{aligned}
& \tau_{R D}=E\left[Y_{i}^{1}-Y_{i}^{0} \mid Z_{i}=c\right]=\lim _{z \downarrow_{c}} E\left[Y_{i}^{1} \mid Z_{i}=z\right]-\lim _{z \uparrow c} E\left[Y_{i}^{0} \mid Z_{i}=z\right]= \\
& E\left[Y_{i}(D=1)-Y_{i}(D=0) \mid Z_{i}=c\right]
\end{aligned}
$$

The treatment effect is indentified if the conditional mean $Y^{0}$ is continuous at $c$. Under this assumption the treatment effect is obtained by estimating the discontinuity in the empirical function. Then the Regression Discontinuity framework is combined with a Difference-in Difference approach to include also pre and post periods (Cutter and Neidell, 2009; Fremigacci, 2010; Lee and Lemieux, 2010). Thus it is:

$$
\begin{aligned}
& \tau_{R D-D I D}=E\left[Y_{i}(1)-Y_{i}(0) \mid Z_{i}=z, G=1\right]-E\left[Y_{i}(1)-Y_{i}(0) \mid Z_{i}=z, G=0\right]= \\
& \lim _{z \downarrow c} E\left[Y_{i} \mid Z_{i}=z, G=1\right]-\lim _{z \uparrow_{c}} E\left[Y_{i} \mid Z_{i}=z, G=1\right]- \\
& \lim _{z \downarrow c} E\left[Y_{i} \mid Z_{i}=z, G=0\right]-\lim _{z \uparrow_{c}} E\left[Y_{i} \mid Z_{i}=z, G=0\right]
\end{aligned}
$$

, where $\mathrm{G}$ stands for the group, 1 for treatment and 0 for control. Furthermore, the traffic volume levels are used in the estimates. Moreover, in all cases the estimates are examined using the 24 hours per day, as well as, the peak hours of the day, as the latter is closer to fixed labour supply function, because it is usually impossible or very rare for the employees to cancel their trips. Furthermore, in this study additional factors are considered, as humidity, unemployment, area and population of the county among others, which are ignored in previous studies (Schreffler, 2003; Welch et al., 2005; Cutter and Neidell, 2009).

Also the current vanpool program in York County targets usually the employees, therefore it is expected the effects of the warning issues on vanpooling to be stronger during the peak 
hours of the day, if the magnitude of employees' response is strong enough to affect the traffic volume. However, based on the summary statistics, there is a considerable high amount of traffic volume during whole day.

Next the regressions using the sum of the peak hours are presented. In particular, the peak hours are the following: 6:00-10:00 a.m. and 16:00-19:00 p.m. (Cutter and Neidell, 2009). Additionally, the regressions are estimated obtaining the percentage changes in traffic volume from the previous day.By transforming panel data into percentage chane the non-stationarity can be solved.$^{5}$ Furthermore percentage changes make comparisons easy, independent of the measurement units the original variables were measured initially, Finally, percentage changes show exactly - better than the original variables -how big changes really are.

Moreover, the regressions based on hourly data are estimated. At this point it should be noted that when hourly data are used the percentage change refers to the same hours on the previous day. This process is considered for the reason that the traffic volume is uniform during the day.

Relations (1)-(2) are estimated for the whole sample, as well as, for specific ozone forecasting bandwidth $\pm 0.10 \mathrm{ppm}$ based on algorithm suggested by Imbens and Kalyanaraman $^{6}$ (2009). Allowing for various bandwidths, ranging between $\pm 0.04- \pm 0.10$

\footnotetext{
${ }^{5}$ For example the traffic volume in levels is non-stationary based on Im-Pesaran-Shin unit-root test giving a pvalue equal to 0.7867 . On the other hand the respective $\mathrm{p}$-value for percentage change in traffic volume is zero.

${ }^{6}$ The optimal bandwidth for the regression discontinuity estimator is given by:

$\hat{h}_{\text {optimum }}=C_{K}\left(\frac{2 \hat{\sigma}^{2}(c) / \hat{f}(c)}{\left(\hat{m}_{+}^{2}(c)-\hat{m}_{-}^{2}(c)\right)^{2}+\left(\hat{r}_{+}+\hat{r}_{-}\right)}\right)^{1 / 5} N^{-1 / 5}$, where $\hat{m}_{+}^{2}(c)$ and $\hat{m}_{-}^{2}(c)$ are the rightside and left-side second derivatives (curvature) of an estimated regression of the outcome variable $\mathrm{Y}$ on the forcing variable $\mathrm{X}$ evaluated at the threshold, $\mathrm{N}$ is the number of observations, $\hat{\sigma}^{2}(c)$ is the estimated standard error, $\hat{f}(c)$ is the density of the forcing variable $\hat{r}_{+}$and $\hat{r}_{-}$is a regularization term (the approximate variance of the estimated curvature) and $C_{K}$ is a constant specific to the Kernel $K$.
} 
ppm, the results are very similar. For shorter bandwidths, especially, \pm 0.01 , there are not enough observations. ${ }^{7}$

\section{Results}

5.1 Traffic volume differences between York and Spartanburg County

In figures 1-2 the histograms for traffic volume during 2006-2007 are presented. It can be observed that the volume of traffic between Spartanburg and York are similar, while the traffic volume presents a higher frequency around 50,000. Also, in figures - 3-4 the histograms for traffic volume during 2008-2010 are presented. In that case the histograms are again very similar between York and Spartanburg County, as a strong positive skewness is observed among all counties ranging between 0.58 and 0.77 .

\section{(Enter Figures 1-4)}

In table 3 the results of DID model of equation (1), taking the interaction term of whether an smog alert is issued in the treatment County, using daily data are provided. More specifically, in columns (1) and (2) the DID results during periods 2006-2007 and 2008-2010 respectively are shown. Additionally, in columns (3) and (4) the results considering the percentage changes of traffic volume are reported. Regarding the total hours and the peak hours of the day during all days of the week, the results are statistically insignificant, based on panels A and B. More specifically, panels A and B present the estimates for the total and peak only hours of the day respectively. Based on panel A, the dummy for treatment group is significant and positive only when the period 2008-2010 and level of traffic volume are considered. The interaction term of

\footnotetext{
${ }^{7}$ It should be noted that the bandwidth is similar to the one used in Cutter and Neidell's (2009) study.
} 
smog alert and treatment County is insignificant in all cases. On the other hand, based on panel B and the peak hours of the day, a significant percentage decrease in treatment group-York county- is reported, equal at 6.218 and 4.142 for periods 2006-2007 and 2008-2010 respectively. However, the interaction term smog alert and treatment county, is insignificant. Panels C and D the exactly same results are reported, with the difference that the sample is restricted only on the days between Monday-Friday. Concerning panel $\mathrm{C}$ and the total hours of the day, during period 2006-2007 the interaction term of treatment County and smog alert dummy is positive and significant, equal at 2,398 regarding the levels of traffic volume and equal at 15.868 per cent when percentage change of traffic volume is considered.

On the other hand, when the peak hours of the day are taken into consideration, based on panel D, the percentage change of traffic volume is positive and significant during 2006-2007 and equal at 13.732 per cent. On the contrary, the coefficient of the interaction term of treatment County and smog alert dummy becomes negative and equal at 6.270 per cent, during period 2008-2010. This indicates that the vanpool programme, becomes more efficient after the change of the threshold during Monday-Friday.

Table 3. Differences-in-Differences (DID) estimates of equation (1)

\begin{tabular}{ccccc}
\hline & $\begin{array}{c}(1) \\
\text { Period 2006-2007 } \\
\text { DV: Traffic } \\
\text { Volume Levels }\end{array}$ & $\begin{array}{c}\text { Period 2008-2010 } \\
\text { DV: Traffic } \\
\text { Volume Levels }\end{array}$ & $\begin{array}{c}(3) \\
\text { Period 2006-2007 } \\
\text { DV: Traffic Volume } \\
\text { Percentage Change }\end{array}$ & $\begin{array}{c}\text { Period 2008-2010 } \\
\text { DV: Traffic Volume } \\
\text { Percentage Change }\end{array}$ \\
\hline $\begin{array}{c}\text { Panel A: Total hours of the day } \\
\text { Dummy (1 for Treatment- } \\
\text { York County) }\end{array}$ & 17.364 & $2,474.91^{*}$ & 8.309 & 21.988 \\
& $(15.611)$ & $(1,150.702)$ & $(7.298)$ & $(16.613)$ \\
Dummy (1 for Smog & 49.967 & 763.398 & $-10.046^{*}$ & $7.156^{* * * *}$ \\
Alert) & $(580.602)$ & $(2,004.385)$ & $(5.396)$ & $(1.787)$ \\
Dummy: Interaction term & $2,088.112$ & $2,542.511$ & 13.858 & 16.993 \\
of Treatment and Smog & $(1,502.796)$ & $(2,842.724)$ & $(11.410)$ & $(15.069)$ \\
Alert & & & \\
R & & 0.8729 & 0.9124 & 0.3698 \\
obs & 0.9023 & 4,941 & 2,136 & 3,993 \\
\hline
\end{tabular}




\begin{tabular}{|c|c|c|c|c|}
\hline \multicolumn{5}{|c|}{ Panel B: Peak hours of the day } \\
\hline $\begin{array}{c}\text { Dummy ( } 1 \text { for Treatment- } \\
\text { York County) }\end{array}$ & $\begin{array}{l}-2,022.81 \\
(4,642.36)\end{array}$ & $\begin{array}{c}140.468 \\
(467.202)\end{array}$ & $\begin{array}{l}-6.218 * * * \\
(0.963)\end{array}$ & $\begin{array}{c}-4.142 * * * \\
(0.375)\end{array}$ \\
\hline $\begin{array}{c}\text { Dummy (1 for Smog } \\
\text { Alert) }\end{array}$ & $\begin{array}{l}287.243 \\
(295.664)\end{array}$ & $\begin{array}{c}1,285.035 * * \\
(628.928)\end{array}$ & $\begin{array}{l}4.414 * * \\
(2.204)\end{array}$ & $\begin{array}{l}10.009 * * * \\
(0.908)\end{array}$ \\
\hline $\begin{array}{c}\text { Dummy: Interaction term } \\
\text { of Treatment and Smog } \\
\text { Alert }\end{array}$ & $\begin{array}{c}610.509 \\
(715.978)\end{array}$ & $\begin{array}{c}1,376.425 \\
(1,605.587)\end{array}$ & $\begin{array}{c}14.076 \\
(12.205)\end{array}$ & $\begin{array}{c}4.702 \\
(3.197)\end{array}$ \\
\hline $\begin{array}{c}\mathrm{R}^{2} \\
\mathrm{obs}\end{array}$ & $\begin{array}{c}0.8477 \\
3,294\end{array}$ & $\begin{array}{c}0.8220 \\
4,941\end{array}$ & $\begin{array}{c}0.9392 \\
2,122\end{array}$ & $\begin{array}{c}0.9357 \\
3,981\end{array}$ \\
\hline $\begin{array}{l}\text { Dummy (1 for Treatment- } \\
\text { York County) }\end{array}$ & $\begin{array}{l}\text { el } \text { Total hou } \\
\quad-5,738.19 \\
(3,587.21)\end{array}$ & $\begin{array}{l}\text { the day betwe } \\
\qquad 619.137 \\
(720.621)\end{array}$ & $\begin{array}{l}\text { day-Friday } \\
5.533 \\
(5.270)\end{array}$ & $\begin{array}{l}-10.517 * * * \\
(2.463)\end{array}$ \\
\hline $\begin{array}{c}\text { Dummy (1 for Smog } \\
\text { Alert) }\end{array}$ & $\begin{array}{c}-1,101.583 * * * \\
\quad(303.278)\end{array}$ & $\begin{array}{c}555.643 \\
(439.151)\end{array}$ & $\begin{array}{c}3.513 \\
(5.055)\end{array}$ & $\begin{array}{c}8,074 \\
(6.777)\end{array}$ \\
\hline $\begin{array}{c}\text { Dummy: Interaction term } \\
\text { of Treatment and Smog } \\
\text { Alert }\end{array}$ & $\begin{array}{c}2,398.377 \\
(789.909)^{* *}\end{array}$ & $\begin{array}{c}918.774 \\
(1,221.285)\end{array}$ & $\begin{array}{c}15.868 \\
(6.906)^{*}\end{array}$ & $\begin{array}{c}16.137 \\
(20.566)\end{array}$ \\
\hline $\begin{array}{l}\mathrm{R}^{2} \\
\mathrm{obs}\end{array}$ & $\begin{array}{c}0.9449 \\
2,340\end{array}$ & $\begin{array}{c}0.9006 \\
3,537\end{array}$ & $\begin{array}{c}0.9244 \\
1,526\end{array}$ & $\begin{array}{c}0.3233 \\
2,866\end{array}$ \\
\hline $\begin{array}{l}\text { Dummy (1 for Treatment- } \\
\text { York County) }\end{array}$ & $\begin{array}{l}\text { nel D: Peak hou } \\
\quad-3,117.86 \\
(5,786.51)\end{array}$ & $\begin{array}{l}\text { the day betwe } \\
1,129.014 \\
(739.369)\end{array}$ & $\begin{array}{c}\text { day-Friday } \\
9.817 * * * \\
(1.673)\end{array}$ & $\begin{array}{c}-8.791 * * * \\
(0.373)\end{array}$ \\
\hline $\begin{array}{c}\text { Dummy (1 for Smog } \\
\text { Alert) }\end{array}$ & $\begin{array}{c}-332.537 * * \\
(158.022)\end{array}$ & $\begin{array}{c}12.309 \\
(258.117)\end{array}$ & $\begin{array}{l}15.233 * * * \\
(0.209)\end{array}$ & $\begin{array}{l}2.141 * * * \\
(0.0580)\end{array}$ \\
\hline $\begin{array}{c}\text { Dummy: Interaction term } \\
\text { of Treatment and Smog } \\
\text { Alert }\end{array}$ & $\begin{array}{c}639.838 \\
(311.190)^{*}\end{array}$ & $\begin{array}{c}298.780 \\
(374.444)\end{array}$ & $\begin{array}{c}13.732 \\
(7.008)^{*}\end{array}$ & $\begin{array}{c}-6.270 \\
(2.305)^{* *}\end{array}$ \\
\hline $\begin{array}{c}\mathrm{R}^{2} \\
\text { obs }\end{array}$ & $\begin{array}{c}0.9481 \\
2,340\end{array}$ & $\begin{array}{c}0.9105 \\
3,537\end{array}$ & $\begin{array}{c}0.9631 \\
1,525\end{array}$ & $\begin{array}{c}0.9628 \\
2,856\end{array}$ \\
\hline
\end{tabular}

The findings in panels C and D are not consistent with Cutter and Neidell's (2009) results, where an insignificant difference between the treatment and control group using the whole sample is reported. However, the Cutter and Neidell's (2009) do not examine the effects of vanpool programme. On the other hand, these findings are in line with the study by Friedman et al. (2001) who found a significant reduction especially during the morning peak hours.

The results using the same equation as in table 3 with a bandwidth of \pm 0.10 are reported in table 4. Based on panel A and the total hours of the day the estimates for the dummy interaction term of alert smog and the treatment County are insignificant. On the contrary, regarding panel 
B and only the peak hours of the day, the interaction term coefficient becomes positive and significant during period 2008-2010. More specifically, the traffic volume is 4,089 more in treatment group, while the percentage change is 18.575 per cent. The results, in that case, show that the traffic volume in York County was more than Spartanburg County. In figures 5-6 the RDD-DID “jump” during period 2008-2010, when the total and peak hours of the day of panels A and B are respectively considered.

Additionally, based on panel $\mathrm{C}$ and the total hours of the day, during only the days between Monday and Friday, the estimates of the main interest coefficient of the interaction term alert and treatment County are insignificant. On the contrary based on panel D and period 20082010, the traffic volume is 4.957 per cent less in treatment group. These findings are consistent to the estimates found by Cutter and Neidell (2009), where a significant decrease on the traffic volume in the treatment group is reported, when a regression discontinuity design is taken into consideration.

Table 4. Differences-in-Differences (DID) - Regression Discontinuity Design (RDD) estimates for equation (3) for the total hours of the day using a window of \pm 0.10

\begin{tabular}{|c|c|c|c|c|}
\hline & $\begin{array}{c}(1) \\
\text { Period 2006-2007 } \\
\text { DV: Traffic } \\
\text { Volume Levels }\end{array}$ & $\begin{array}{c}(2) \\
\text { Period 2008-2010 } \\
\text { DV: Traffic } \\
\text { Volume Levels }\end{array}$ & $\begin{array}{c}(3) \\
\text { Period 2006-2007 } \\
\text { DV: Traffic } \\
\text { Volume } \\
\text { Percentage } \\
\text { Change }\end{array}$ & $\begin{array}{c}(4) \\
\text { Period 2008-2010 } \\
\text { DV: Traffic } \\
\text { Volume } \\
\text { Percentage } \\
\text { Change }\end{array}$ \\
\hline \multicolumn{5}{|c|}{ Panel A: Total hours of the day } \\
\hline $\begin{array}{c}\text { Dummy ( } 1 \text { for Treatment- York } \\
\text { County) }\end{array}$ & $\begin{array}{c}31.954 \\
(57.917)\end{array}$ & $\begin{array}{c}2,679.815 \\
(1,737.509)\end{array}$ & $\begin{array}{c}8.316 \\
(5.066)\end{array}$ & $\begin{array}{c}4.896 \\
(8.107)\end{array}$ \\
\hline Dummy (1 for Smog Alert) & $\begin{array}{c}-3,952.374 * * \\
(1,598.857)\end{array}$ & $\begin{array}{c}2,119.798 \\
(2,558.621)\end{array}$ & $\begin{array}{c}-11.955^{* * *} * \\
(2.888)\end{array}$ & $\begin{array}{l}-4.970 \\
(4.797)\end{array}$ \\
\hline $\begin{array}{c}\text { Dummy: Interaction term of } \\
\text { Treatment and Smog Alert } \\
\mathrm{R}^{2} \\
\text { obs }\end{array}$ & $\begin{array}{c}557.629 \\
(2,489.353) \\
0.9525 \\
422 \\
\text { Panel B: Peal }\end{array}$ & 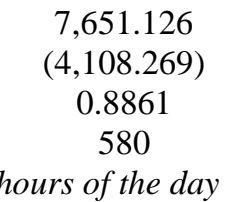 & $\begin{array}{c}-22.337 \\
(13.648) \\
0.9779 \\
298\end{array}$ & $\begin{array}{c}13.086 \\
(3.586) \\
0.9686 \\
525\end{array}$ \\
\hline
\end{tabular}




\begin{tabular}{|c|c|c|c|c|}
\hline $\begin{array}{c}\text { Dummy (1 for Treatment- York } \\
\text { County) }\end{array}$ & $\begin{array}{l}-715.821^{*} \\
(375.751)\end{array}$ & $\begin{array}{l}1,444.196 \\
(953.244)\end{array}$ & $\begin{array}{l}-3.327^{*} \\
(1.748)\end{array}$ & $\begin{array}{l}-0.3714 \\
(4.667)\end{array}$ \\
\hline Dummy (1 for Smog Alert) & $\begin{array}{c}-1,559.559 * * \\
\quad(686.157)\end{array}$ & $\begin{array}{c}1,152.617 \\
(1,210.887)\end{array}$ & $\begin{array}{l}-12.859 * * * \\
(3.706)\end{array}$ & $\begin{array}{l}12.578 * * \\
(4.434)\end{array}$ \\
\hline $\begin{array}{c}\text { Dummy: Interaction term of } \\
\text { Treatment and Smog Alert } \\
\mathrm{R}^{2} \\
\text { obs }\end{array}$ & $\begin{array}{c}637.174 \\
(1,457.786) \\
0.9151 \\
422\end{array}$ & $\begin{array}{c}4,089.62 * \\
(1,997.619) \\
0.8760 \\
580\end{array}$ & $\begin{array}{c}-19.190 \\
(16.113) \\
0.9734 \\
298\end{array}$ & $\begin{array}{c}18.575^{* *} \\
(6.672) \\
0.9591 \\
525\end{array}$ \\
\hline $\begin{array}{c}\text { Panel } \\
\text { Dummy (1 for Treatment- York } \\
\text { County) }\end{array}$ & $\begin{array}{l}\text { Total hours of } t \\
\quad-1,376.564 \\
(1,344.211)\end{array}$ & $\begin{array}{c}y \text { between } M c \\
-1,376.564 \\
(1,344.211)\end{array}$ & $\begin{array}{l}\text { Friday } \\
\quad-4.970 \\
\quad(4.797)\end{array}$ & $\begin{array}{l}-2.444 * * \\
(1.212)\end{array}$ \\
\hline Dummy (1 for Smog Alert) & $\begin{array}{l}-2,309.268 \\
(3,686.924)\end{array}$ & $\begin{array}{c}780.727 \\
(850.651)\end{array}$ & $\begin{array}{c}4.896 \\
(8.107)\end{array}$ & $\begin{array}{l}0.7335 \\
(3.675)\end{array}$ \\
\hline $\begin{array}{c}\text { Dummy: Interaction term of } \\
\text { Treatment and Smog Alert } \\
\mathrm{R}^{2} \\
\text { obs }\end{array}$ & $\begin{array}{c}-227.53 \\
(4,459.955) \\
0.9691 \\
324\end{array}$ & $\begin{array}{c}4,244.095 \\
(4,178.918) \\
0.9483 \\
489\end{array}$ & $\begin{array}{c}-8.350 \\
(36.757) \\
0.9910 \\
229\end{array}$ & $\begin{array}{c}3.055 \\
(4.535) \\
0.9766 \\
442\end{array}$ \\
\hline \multicolumn{5}{|c|}{ Panel D: Peak hours of the day between Monday-Friday } \\
\hline $\begin{array}{c}\text { Dummy (1 for Treatment- York } \\
\text { County) }\end{array}$ & $\begin{array}{c}-586.670 \\
(2,282.252)\end{array}$ & $\begin{array}{l}-350.123 \\
(768.959)\end{array}$ & $\begin{array}{c}1.464 \\
(1.260)\end{array}$ & $\begin{array}{l}-11.903 * * * \\
(4.926)\end{array}$ \\
\hline Dummy (1 for Smog Alert) & $\begin{array}{l}-1,343.120 \\
(1,439.968)\end{array}$ & $\begin{array}{c}161.010 \\
(1,067.38)\end{array}$ & $\begin{array}{l}-6.496 \\
(5.172)\end{array}$ & $\begin{array}{c}2.513 \\
(2.777)\end{array}$ \\
\hline $\begin{array}{l}\text { Dummy: Interaction term of } \\
\text { Treatment and Smog Alert }\end{array}$ & $\begin{array}{c}1,385.671 \\
(3,394.037)\end{array}$ & $\begin{array}{c}1,515.534 \\
(1,584.537)\end{array}$ & $\begin{array}{c}8.624 \\
(32.593)\end{array}$ & $\begin{array}{l}-4.957 * * \\
(1.508)\end{array}$ \\
\hline $\begin{array}{l}\mathrm{R}^{2} \\
\text { obs }\end{array}$ & $\begin{array}{c}0.9704 \\
324\end{array}$ & $\begin{array}{c}0.9271 \\
489\end{array}$ & $\begin{array}{c}0.9909 \\
229\end{array}$ & $\begin{array}{c}0.9706 \\
442\end{array}$ \\
\hline
\end{tabular}

Table 5. Differences-in-Differences (DID) estimates of equation (1) using hourly data

\begin{tabular}{|c|c|c|c|c|}
\hline & $\begin{array}{c}(1) \\
\text { Period 2006-2007 } \\
\text { DV: Traffic } \\
\text { Volume Levels }\end{array}$ & $\begin{array}{c}(2) \\
\text { Period 2008-2010 } \\
\text { DV: Traffic } \\
\text { Volume Levels }\end{array}$ & $\begin{array}{c}(3) \\
\text { Period 2006-2007 } \\
\text { DV: Traffic } \\
\text { Volume } \\
\text { Percentage } \\
\text { Change } \\
\end{array}$ & $\begin{array}{c}(4) \\
\text { Period 2008-2010 } \\
\text { DV: Traffic } \\
\text { Volume } \\
\text { Percentage } \\
\text { Change } \\
\end{array}$ \\
\hline \multicolumn{5}{|c|}{ Panel A: Total hours of the day } \\
\hline $\begin{array}{c}\text { Dummy (1 for Treatment- } \\
\text { York County) }\end{array}$ & $\begin{array}{l}5,914.968 \\
(2,406.603)\end{array}$ & $\begin{array}{r}-118.172 \\
(87.948)\end{array}$ & $\begin{array}{c}-4.921 * * * \\
(0.831)\end{array}$ & $\begin{array}{l}-3.691 \\
(0.613)\end{array}$ \\
\hline $\begin{array}{c}\text { Dummy (1 for Smog } \\
\text { Alert) }\end{array}$ & $\begin{array}{c}12.551 \\
(12.463)\end{array}$ & $\begin{array}{l}140.714 * * * \\
(14.564)\end{array}$ & $\begin{array}{l}2.704 * * * \\
(0.712)\end{array}$ & $\begin{array}{l}12.300^{* * * *} \\
(0.847)\end{array}$ \\
\hline $\begin{array}{c}\text { Dummy: Interaction term } \\
\text { of Treatment and Smog } \\
\text { Alert }\end{array}$ & $\begin{array}{l}95.458 \\
(72.615)\end{array}$ & $\begin{array}{c}121.068 \\
(121.453)\end{array}$ & $\begin{array}{c}35.984 \\
(24.660)\end{array}$ & $\begin{array}{l}-2.772 \\
(3.826)\end{array}$ \\
\hline $\mathrm{R}^{2}$ & 0.7796 & 0.7744 & 0.7137 & 0.7957 \\
\hline obs & 62,394 & 110,204 & 53,504 & 96,929 \\
\hline
\end{tabular}




\begin{tabular}{|c|c|c|c|c|}
\hline \multicolumn{5}{|c|}{ Panel B: Peak hours of the day } \\
\hline $\begin{array}{c}\text { Dummy ( } 1 \text { for Treatment- } \\
\text { York County) }\end{array}$ & $\begin{array}{l}3,529.791 \\
(3,865.96)\end{array}$ & $\begin{array}{l}-184.216 \\
(209.235)\end{array}$ & $\begin{array}{l}-9.192 * * * \\
(1.872)\end{array}$ & $\begin{aligned}- & 7.113 * * * \\
& (1.351)\end{aligned}$ \\
\hline $\begin{array}{c}\text { Dummy (1 for Smog } \\
\text { Alert) }\end{array}$ & $\begin{array}{c}37.342 \\
(29.633)\end{array}$ & $\begin{array}{c}185.288 * * * \\
(34.652)\end{array}$ & $\begin{array}{c}6.415 * * * \\
(1.609)\end{array}$ & $\begin{array}{l}13.936 * * * \\
(1.871)\end{array}$ \\
\hline $\begin{array}{c}\text { Dummy: Interaction term } \\
\text { of Treatment and Smog } \\
\text { Alert }\end{array}$ & $\begin{array}{c}93.279 \\
(108.038)\end{array}$ & $\begin{array}{c}185.228 \\
(199.083)\end{array}$ & $\begin{array}{l}33.330 \\
(21.542)\end{array}$ & $\begin{array}{l}4.260 \\
(2.975)\end{array}$ \\
\hline $\begin{array}{c}\mathrm{R}^{2} \\
\mathrm{obs}\end{array}$ & $\begin{array}{l}0.7721 \\
20,794\end{array}$ & $\begin{array}{l}0.7729 \\
36,741\end{array}$ & $\begin{array}{l}0.6950 \\
17,832\end{array}$ & $\begin{array}{l}0.7385 \\
80,878\end{array}$ \\
\hline $\begin{array}{l}\text { Dummy (1 for Treatment- } \\
\text { York County) }\end{array}$ & $\begin{array}{c}\text { : Total hour } \\
2,709.564 \\
(2,618.214)\end{array}$ & $\begin{array}{c}\text { day betweet } \\
28.127 \\
(91.457)\end{array}$ & $\begin{array}{l}\text { lay-Friday } \\
-0.0448 \\
(0.656)\end{array}$ & $\begin{array}{l}0.856 * \\
(0.507)\end{array}$ \\
\hline $\begin{array}{c}\text { Dummy (1 for Smog } \\
\text { Alert) }\end{array}$ & $\begin{array}{l}-29.051 * * \\
(12.540)\end{array}$ & $\begin{array}{l}42.185 * * * \\
(13.697)\end{array}$ & $\begin{array}{l}-2.528 * * * \\
(0.537)\end{array}$ & $\begin{array}{l}6.560 * * * \\
(0.640)\end{array}$ \\
\hline $\begin{array}{c}\text { Dummy: Interaction term } \\
\text { of Treatment and Smog } \\
\text { Alert }\end{array}$ & $\begin{array}{c}95.537 \\
(33.577)\end{array}$ & $\begin{array}{c}71.984 \\
(57.871)\end{array}$ & $\begin{array}{l}34.430 \\
(25.785)\end{array}$ & $\begin{array}{l}-6.470 \\
(7.281)\end{array}$ \\
\hline $\begin{array}{l}\mathrm{R}^{2} \\
\text { obs }\end{array}$ & $\begin{array}{l}0.8220 \\
44,581\end{array}$ & $\begin{array}{l}0.8137 \\
78,877\end{array}$ & $\begin{array}{l}0.7100 \\
38,291\end{array}$ & $\begin{array}{l}0.7998 \\
69,354\end{array}$ \\
\hline $\begin{array}{l}\text { Dummy (1 for Treatment- } \\
\text { York County) }\end{array}$ & $\begin{array}{l}\text { D: Peak hour: } \\
5,719.319 \\
(6,160.173)\end{array}$ & $\begin{array}{l}\text { day betweer } \\
-92.671^{*} \\
(52.070)\end{array}$ & $\begin{array}{l}\text { lay-Friday } \\
5.817 * * * \\
(0.966)\end{array}$ & $\begin{array}{l}-4.961 * * * \\
(0.719)\end{array}$ \\
\hline $\begin{array}{c}\text { Dummy (1 for Smog } \\
\text { Alert) }\end{array}$ & $\begin{array}{l}-18.566 \\
(29.509)\end{array}$ & $\begin{array}{c}-1.337 \\
(31.765)\end{array}$ & $\begin{array}{c}-1.909 * * * \\
(0.792)\end{array}$ & $\begin{array}{l}2.211^{* * *} * \\
(0.908)\end{array}$ \\
\hline $\begin{array}{c}\text { Dummy: Interaction term } \\
\text { of Treatment and Smog } \\
\text { Alert }\end{array}$ & $\begin{array}{l}75.258 \\
(27.528)\end{array}$ & $\begin{array}{l}-114.351^{*} \\
(61.218)\end{array}$ & $\begin{array}{c}28.127 \\
(21.727)\end{array}$ & $\begin{array}{c}-7.054 * * * \\
\quad(1.735)\end{array}$ \\
\hline $\begin{array}{c}\mathrm{R}^{2} \\
\mathrm{obs}\end{array}$ & $\begin{array}{l}0.8538 \\
14,862\end{array}$ & $\begin{array}{l}0.8485 \\
26,297\end{array}$ & $\begin{array}{l}0.6949 \\
12,764\end{array}$ & $\begin{array}{l}0.7500 \\
23,124\end{array}$ \\
\hline
\end{tabular}

Then the estimates obtaining hourly data are presented. Based on the results of table 5 the estimates are insignificant in all cases, with the exception of panel D and column (4), for the percentage of traffic volume and when only the peak hours of the day during the days MondayFriday are considered.

More specifically, there is a significant reduction equal to 7.054 per cent based on the coefficient of the interaction term between the treatment County and the smog alert day. The findings are in line with the study by Cutter and Neidell (2009) who found a reduction on trips equal at 4.5 per cent. Similarly, other studies report a reduction on trips and traffic volume ranging between 4.8-5.0 per cent (Schreffler, 2003; Lu et al., 2004). However, it should be 
noticed that these studies do not examine peak hours and hourly data, as well as, the days between Monday-Friday are not considered into the analysis.

Similarly, the results of table 5 using hourly data with a bandwidth of \pm 0.10 ppm are presented in table6. In that case only the percentage change of traffic volume during peak hours of the day are significant, based on panels B and D and column (4), with values -9.129 and 9.825 respectively. More specifically, panel B denotes the peak hours of the day, while in panel D the estimates, when only the peak hours of the day during the days Monday and Friday are taken into consideration, are reported. Moreover, column (4) indicates the percentage change of traffic volume during period 2008-2010. Therefore, the interaction term of treatment and smog alert is negative and significant. This indicates that during the peak hours of the day between Monday-Friday during period 2008-2010, the traffic volume is decreased by 9-10 per cent in the treatment group- York County- in comparison with the control group, which is the Spartanburg County. The results, using hourly data, are different, when the daily data are considered. This is explained by the fact that the percentage change is referred to the same hours between the days, as it has been discussed in the methodology part.

Table 6. Differences-in-Differences (DID) - Regression Discontinuity Design (RDD) estimates of equation (3) with a window of \pm 0.10 using hourly data

\begin{tabular}{|c|c|c|c|c|}
\hline & $\begin{array}{c}(1) \\
\text { Period 2006-2007 } \\
\text { DV: Traffic } \\
\text { Volume Levels }\end{array}$ & $\begin{array}{c}(2) \\
\text { Period 2008-2010 } \\
\text { DV: Traffic } \\
\text { Volume Levels }\end{array}$ & $\begin{array}{c}(3) \\
\text { Period 2006-2007 } \\
\text { DV: Traffic } \\
\text { Volume } \\
\text { Percentage } \\
\text { Change }\end{array}$ & $\begin{array}{c}(4) \\
\text { Period 2008-2010 } \\
\text { DV: Traffic } \\
\text { Volume } \\
\text { Percentage } \\
\text { Change }\end{array}$ \\
\hline \multicolumn{5}{|c|}{ Panel A: Total hours of the day } \\
\hline $\begin{array}{c}\text { Dummy ( } 1 \text { for Treatment- } \\
\text { York County) }\end{array}$ & $\begin{array}{l}17.144 \\
(32.899)\end{array}$ & $\begin{array}{l}-61.830 \\
(68.380)\end{array}$ & $\begin{array}{c}5.302 \\
(4.374)\end{array}$ & $\begin{array}{l}-3.714 \\
(3.236)\end{array}$ \\
\hline $\begin{array}{c}\text { Dummy (1 for Smog } \\
\text { Alert) }\end{array}$ & $\begin{array}{c}-147.695 * * * \\
(37.666)\end{array}$ & $\begin{array}{l}226.491 \\
(36.994)\end{array}$ & $\begin{array}{c}-13.526 * * * \\
(2.327)\end{array}$ & $\begin{array}{l}9.283 * * * \\
(2.021)\end{array}$ \\
\hline $\begin{array}{c}\text { Dummy: Interaction term } \\
\text { of Treatment and Smog } \\
\text { Alert }\end{array}$ & $\begin{array}{l}113.934 \\
(68.955)\end{array}$ & $\begin{array}{c}79.397 \\
(71.534)\end{array}$ & $\begin{array}{l}-19.703 \\
(14.981)\end{array}$ & $\begin{array}{l}-1.172 \\
(2.187)\end{array}$ \\
\hline $\begin{array}{l}\mathrm{R}^{2} \\
\text { obs }\end{array}$ & $\begin{array}{c}0.8028 \\
8,254\end{array}$ & $\begin{array}{l}0.7982 \\
13,212\end{array}$ & $\begin{array}{c}0.7649 \\
7,462\end{array}$ & $\begin{array}{l}0.8276 \\
12,436\end{array}$ \\
\hline \multicolumn{5}{|c|}{ Panel B: Peak hours of the day } \\
\hline
\end{tabular}




\begin{tabular}{|c|c|c|c|c|}
\hline $\begin{array}{c}\text { Dummy (1 for Treatment- } \\
\text { York County) }\end{array}$ & $\begin{array}{l}-123.132 \\
(213.015)\end{array}$ & $\begin{array}{c}-53.232 \\
(153.919)\end{array}$ & $\begin{array}{l}1.635 \\
(8.301)\end{array}$ & $\begin{array}{l}-4.894 \\
(5.758)\end{array}$ \\
\hline $\begin{array}{c}\text { Dummy (1 for Smog } \\
\text { Alert) }\end{array}$ & $\begin{array}{l}-206.443 * * \\
(84.862)\end{array}$ & $\begin{array}{l}396.981 * * * \\
(81.905)\end{array}$ & $\begin{array}{c}-10.831 * * \\
(4.698)\end{array}$ & $\begin{array}{l}22.737 * * * \\
(3.975)\end{array}$ \\
\hline $\begin{array}{c}\text { Dummy: Interaction term } \\
\text { of Treatment and Smog } \\
\text { Alert }\end{array}$ & $\begin{array}{c}188.219 \\
(107.533)\end{array}$ & $\begin{array}{c}107.307 \\
(105.808)\end{array}$ & $\begin{array}{l}-13.997 \\
(13.144)\end{array}$ & $\begin{array}{l}-9.129 \\
(3.300)^{* *}\end{array}$ \\
\hline $\begin{array}{l}\mathrm{R}^{2} \\
\text { obs }\end{array}$ & $\begin{array}{c}0.8084 \\
2,752\end{array}$ & $\begin{array}{c}0.8181 \\
4,404\end{array}$ & $\begin{array}{c}0.7165 \\
2,488\end{array}$ & $\begin{array}{c}0.7768 \\
4,144\end{array}$ \\
\hline $\begin{array}{l}\text { Par } \\
\text { Dummy (1 for Treatment- } \\
\text { York County) }\end{array}$ & $\begin{array}{c}\text { C: Total hour } \\
-1,376.564 \\
(1,344.211)\end{array}$ & $\begin{array}{c}\text { e day betweer } \\
283.224 \\
(377.329)\end{array}$ & $\begin{array}{l}\text { lay-Friday } \\
\quad-46.858 \\
(88.246)\end{array}$ & $\begin{array}{l}-5.562 * \\
(2.886)\end{array}$ \\
\hline $\begin{array}{c}\text { Dummy (1 for Smog } \\
\text { Alert) }\end{array}$ & $\begin{array}{l}-2,309.268 \\
(3,686.924)\end{array}$ & $\begin{array}{l}129.953 \\
(47.485)\end{array}$ & $\begin{array}{l}-49.513 \\
(53.284)\end{array}$ & $\begin{array}{c}2.075 \\
(2.026)\end{array}$ \\
\hline $\begin{array}{c}\text { Dummy: Interaction term } \\
\text { of Treatment and Smog } \\
\text { Alert }\end{array}$ & $\begin{array}{l}78.467 \\
(45.776)\end{array}$ & $\begin{array}{l}-122.797 * \\
(71.684)\end{array}$ & $\begin{array}{l}-41.320 \\
(22.889)\end{array}$ & $\begin{array}{l}-0.794 \\
(4.503)\end{array}$ \\
\hline $\begin{array}{l}\mathrm{R}^{2} \\
\mathrm{obs}\end{array}$ & $\begin{array}{c}0.8294 \\
6,335\end{array}$ & $\begin{array}{l}0.8224 \\
11,124\end{array}$ & $\begin{array}{c}0.7620 \\
5,711\end{array}$ & $\begin{array}{l}0.8300 \\
10,444\end{array}$ \\
\hline \multicolumn{5}{|c|}{ Panel D: Peak hours of the day between Monday-Friday } \\
\hline $\begin{array}{c}\text { Dummy (1 for Treatment- } \\
\text { York County) }\end{array}$ & $\begin{array}{l}-136.174 \\
(209.765)\end{array}$ & $\begin{array}{l}-125.996 \\
(160.785)\end{array}$ & $\begin{array}{c}1.317 \\
(2.316)\end{array}$ & $\begin{array}{l}-8.473 * * \\
(3.613)\end{array}$ \\
\hline $\begin{array}{c}\text { Dummy (1 for Smog } \\
\text { Alert) }\end{array}$ & $\begin{array}{l}-102.473 \\
(119.032)\end{array}$ & $\begin{array}{l}178.998 * \\
(104.718)\end{array}$ & $\begin{array}{l}-3.157 \\
(2.890)\end{array}$ & $\begin{array}{c}2.721 \\
(2.573)\end{array}$ \\
\hline $\begin{array}{c}\text { Dummy: Interaction term } \\
\text { of Treatment and Smog } \\
\text { Alert }\end{array}$ & $\begin{array}{c}27.819 \\
(42.574)\end{array}$ & $\begin{array}{l}-59.345 \\
(52.003)\end{array}$ & $\begin{array}{l}-30.877 \\
(18.930)\end{array}$ & $\begin{array}{l}-9.825 * \\
(4.414)\end{array}$ \\
\hline $\begin{array}{l}\mathrm{R}^{2} \\
\text { obs }\end{array}$ & $\begin{array}{c}0.8595 \\
2,112\end{array}$ & $\begin{array}{c}0.8574 \\
3,708\end{array}$ & $\begin{array}{c}0.7217 \\
1,904\end{array}$ & $\begin{array}{c}0.3789 \\
4,287\end{array}$ \\
\hline
\end{tabular}

Additionally, the model controls for hours, as each hour of the day might have a different impact on traffic volume.

\subsection{Change of threshold and traffic}

In table 7 the estimates of model (2), where the interaction term refers on whether a smog alert is issued in the treatment group during period 2008-2010 are reported. More precisely, the first dummy indicates if there is a smog alert in the treatment group-York County- or not, while the second dummy equal to 1 for the post period 2008-2010 and 0 otherwise-period 2006-2007. 
Finally, the third variable is the interaction term of whether a smog alert is issued in York County or not and the post period 2008-2010, which is the main interest of the study.

In all cases the results are insignificant with two exceptions. Firstly, in panel A regarding the total hours of the day, the coefficient of the interaction term dummy is negative and significant equal at -14.213 per cent, indicating that the traffic volume in the treatment group is reduced by 14.213 per cent in comparison with the control group, during period 2008-2010.

Similarly, the percentage change of traffic volume using peak hours of the day and during Mondays-Fridays, is equal to -31.909 per cent, based on panel B and column (4), indicating that the traffic volume intensity reduction is even stronger when only the days between Monday-Friday and the peak hours of the day are considered. These findings are inconsistent with Cutter and Neidell's (2009) paper, who found insignificant results when the total sample is considered. However, the approach followed here is different, where the post period is taken into consideration, while is not on Cutter and Neidell's (2009) study. Similarly, Schreffler (2003) found a significant reduction on traffic volume equal at 4.8 per cent, when a smog alert is triggered. However, the effects of vanpool program on traffic are not examined.

Table 7. Differences-in-Differences (DID) estimates of equation (2) using daily data

\begin{tabular}{|c|c|c|c|c|}
\hline & $\begin{array}{c}\text { (1) } \\
\text { Total Hours } \\
\text { of the day } \\
\text { DV: Traffic } \\
\text { Volume Levels }\end{array}$ & $\begin{array}{c}(2) \\
\text { Total Hours } \\
\text { of the day } \\
\text { DV: Traffic Volume } \\
\text { Percentage Change }\end{array}$ & $\begin{array}{c}(3) \\
\text { Peak Hours } \\
\text { of the day } \\
\text { DV: Traffic } \\
\text { Volume Levels }\end{array}$ & $\begin{array}{c}(4) \\
\text { Peak Hours } \\
\text { of the day } \\
\text { DV: Traffic Volume } \\
\text { Percentage Change }\end{array}$ \\
\hline \multicolumn{5}{|c|}{ Panel A: All days of the week using whole sample } \\
\hline $\begin{array}{c}\text { Dummy-Interaction term (1 for } \\
\text { Treatment- York County and Smog } \\
\text { Alert) }\end{array}$ & $\begin{array}{c}2,428.019 \\
(1,772.301)\end{array}$ & $\begin{array}{c}-14.870 * * * \\
(4.649)\end{array}$ & $\begin{array}{c}1,142.367 * \\
(660.413)\end{array}$ & $\begin{array}{l}-18.996 \\
(10.222)\end{array}$ \\
\hline Dummy: 1 for Post Period 2008-2010 & $\begin{array}{l}7,218.627 * \\
(4,294.059)\end{array}$ & $\begin{array}{l}-7.759 \\
(5.428)\end{array}$ & $\begin{array}{l}3,404.038 * \\
(1,815.761)\end{array}$ & $\begin{array}{l}3.815 \\
(2.566)\end{array}$ \\
\hline $\begin{array}{l}\text { Dummy: Interaction term of Treatment- } \\
\text { Smog Alert and Post Period 2008-2010 }\end{array}$ & $\begin{array}{l}-695.560 \\
(3.646 .097)\end{array}$ & $\begin{array}{c}-14.213 * * * \\
(4.850)\end{array}$ & $\begin{array}{c}797.143 \\
(1.576 .168)\end{array}$ & $\begin{array}{l}-22.463 \\
(14.881)\end{array}$ \\
\hline $\mathrm{R}^{2}$ & 0.8755 & 0.4722 & 0.8236 & 0.9354 \\
\hline obs & 8,235 & 6,129 & 8,235 & 6,103 \\
\hline \multicolumn{5}{|c|}{ Panel B: Between Monday-Friday using whole sample } \\
\hline
\end{tabular}




\begin{tabular}{|c|c|c|c|c|}
\hline $\begin{array}{c}\text { Dummy-Interaction term (1 for } \\
\text { Treatment- York County and Smog } \\
\text { Alert) }\end{array}$ & $\begin{array}{c}1,526.789 \\
(1,231.499)\end{array}$ & $\begin{array}{l}8.2581 \\
(5.174)\end{array}$ & $\begin{array}{c}585.560 \\
(592.028)\end{array}$ & $\begin{array}{c}-13.601 * * \\
(0.781)\end{array}$ \\
\hline Dummy: 1 for Post Period 2008-2010 & $\begin{array}{c}6,866.253 \\
(4,566.025)\end{array}$ & $\begin{array}{l}-9.690 \\
(8.493)\end{array}$ & $\begin{array}{l}4,258.856^{*} \\
(2,462.822)\end{array}$ & $\begin{array}{l}-0.8342 \\
(0.6339)\end{array}$ \\
\hline Dummy: Interaction term of Treatment- & $-1,814.441$ & -6.994 & -472.676 & -31.909 \\
\hline Smog Alert and Post Period 2008-2010 & $(3,378.821)$ & $(5.591)$ & $(1,242.185)$ & $(12.168)^{* * *}$ \\
\hline $\mathrm{R}^{2}$ & 0.9097 & 0.4205 & 0.9182 & 0.9620 \\
\hline obs & 5,877 & 4,392 & 5,877 & 4,381 \\
\hline \multicolumn{5}{|c|}{ Panel C: All days of the week using window of \pm 0.10} \\
\hline $\begin{array}{c}\text { Dummy-Interaction term (1 for } \\
\text { Treatment- York County and Smog } \\
\text { Alert) }\end{array}$ & $\begin{array}{c}-2,134.327 * * \\
(898.54)\end{array}$ & $\begin{array}{l}-3.461 \\
(2.002)\end{array}$ & $\begin{array}{c}-1,456.052 * * \\
(564.405)\end{array}$ & $\begin{array}{c}-10.581 * * \\
(3.457)\end{array}$ \\
\hline Dummy: 1 for Post Period 2008-2010 & $\begin{array}{l}1,669.675 \\
(1,408.87)\end{array}$ & $\begin{array}{l}-3.100 \\
(7.572)\end{array}$ & $\begin{array}{l}1,358.133 \\
(743.699)\end{array}$ & $\begin{array}{c}6.054 \\
(4.791)\end{array}$ \\
\hline Dummy: Interaction term of Treatment- & $3,454.594 *$ & -4.497 & $2,218.749 *$ & 1.680 \\
\hline Smog Alert and Post Period 2008-2010 & $(1,612.402)$ & $(8.909)$ & $(1,153.013)$ & $(8.252)$ \\
\hline $\mathrm{R}^{2}$ & 0.8952 & 0.9680 & 0.8735 & 0.9609 \\
\hline obs & 1,002 & 823 & 1,152 & 823 \\
\hline \multicolumn{5}{|c|}{ Panel D: Between Monday-Friday using window of \pm 0.10} \\
\hline $\begin{array}{c}\text { Dummy-Interaction term (1 for } \\
\text { Treatment- York County and Smog } \\
\text { Alert) }\end{array}$ & $\begin{array}{c}-1,278.136 \\
(1,195.257)\end{array}$ & $\begin{array}{c}1.888 \\
(1.624)\end{array}$ & $\begin{array}{l}-298.583 \\
(634.111)\end{array}$ & $\begin{array}{c}-5.900 * * * \\
(1.888)\end{array}$ \\
\hline Dummy: 1 for Post Period 2008-2010 & $\begin{array}{c}-1,404.518 \\
(2,413.113)\end{array}$ & $\begin{array}{l}-8.458 \\
(4.875)\end{array}$ & $\begin{array}{c}-752.891 \\
(1,176.23)\end{array}$ & $\begin{array}{l}-2.522 * \\
(1.335)\end{array}$ \\
\hline Dummy: Interaction term of Treatment- & $2,254.191$ & -13.659 & 713.980 & $-13.800 * * *$ \\
\hline Smog Alert and Post Period 2008-2010 & $(1,027.97)$ & $(11.775)$ & $(416.499)$ & $(4.554)$ \\
\hline $\mathrm{R}^{2}$ & 0.9199 & 0.9783 & 0.9318 & 0.9747 \\
\hline obs & 813 & 671 & 813 & 671 \\
\hline
\end{tabular}

a. Standard errors are reported between brackets,

b. $* * *, * *$ and $*$ denote significance at the $1 \%, 5 \%$ and $10 \%$ level

Despite the fact that the percentage change is positive, when the sample is restricted to a specific bandwidth, based on table 4, using the whole sample and considering the post period 2008-2010, there is a significant decrease in difference of traffic between treatment and control group. This can be explained by the fact that various thresholds exist, based on table 1 . Therefore, the smog alert probably is not enough, but the value of ozone forecasts might play a major role.

Similarly, the estimates for model (4) using the bandwidth of $\pm 0.10 \mathrm{ppm}$ are presented in panels C-D in table 7. More specifically, the estimates are insignificant, with the exception of traffic volume in panel $\mathrm{C}$ and the percentage change in panel D. In particular the traffic volume is 3,454 and 2,218 for total and peak hours of the day respectively, as it can be shown in panel 
A. Regarding, the percentage change in traffic volume, based on panel D and column (4), where only the peak hours of the day, as well as, only the days between Monday and Friday are considered, the coefficient of the interaction term of treatment County and post period is significant and negative equal to -13.800 per cent. These findings are in line with on Cutter and Neidell's (2009) study, where a significant reduction on traffic volume equal at 4.5 per cent is observed when a smog alert is issued. Similarly, Schreffler (2003) found a statistically significant 4.8 percent reduction in trips when smog alerts implemented.

In table 8- the results of the difference-in-difference model examining the effects during the post period 2008-2010 obtaining hourly data are reported. Considering the total hours of the day, the traffic volume is more in York County by 168.392, as it can be shown from coefficient of the interaction term between the smog alert issue in the treatment group and the post period based on panel A and column (1). Similarly, traffic volume is more in York County by 193.914, based on panel B and column (1). Similarly, the traffic volume in treatment group is more by 282.968, when the sample is restricted to the peak hours of the day.

Table 8. Differences-in-Differences (DID) estimates of equation (2) using hourly data

\begin{tabular}{|c|c|c|c|c|}
\hline & $\begin{array}{c}(1) \\
\text { Total Hours } \\
\text { of the day } \\
\text { DV: Traffic Volume } \\
\text { Levels }\end{array}$ & $\begin{array}{c}\text { (2) } \\
\text { Total Hours } \\
\text { of the day } \\
\text { DV: Traffic Volume } \\
\text { Percentage Change }\end{array}$ & $\begin{array}{c}(3) \\
\text { Peak Hours } \\
\text { of the day } \\
\text { DV: Traffic Volume } \\
\text { Levels }\end{array}$ & $\begin{array}{c}(4) \\
\text { Peak Hours } \\
\text { of the day } \\
\text { DV: Traffic Volume } \\
\text { Percentage Change }\end{array}$ \\
\hline \multicolumn{5}{|c|}{ Panel A: All days of the week using whole sample } \\
\hline $\begin{array}{c}\text { Dummy-Interaction term (1 for } \\
\text { Treatment- York County and } \\
\text { Smog Alert) }\end{array}$ & $\begin{array}{l}68.521 * * * \\
(9.736)\end{array}$ & $\begin{array}{c}-14.220^{*} \\
(7.225)\end{array}$ & $\begin{array}{c}97.927 * * * \\
(22.448)\end{array}$ & $\begin{array}{l}-26.541 * * \\
(12.249)\end{array}$ \\
\hline $\begin{array}{l}\text { Dummy: } 1 \text { for Post Period 2008- } \\
\qquad 2010\end{array}$ & $\begin{array}{l}-22.076 \\
(25.445)\end{array}$ & $\begin{array}{l}0.484 * \\
(0.291)\end{array}$ & $\begin{array}{l}-63.900 \\
(59.929)\end{array}$ & $\begin{array}{l}1.660 * \\
(0.881)\end{array}$ \\
\hline $\begin{array}{l}\text { Dummy: Interaction term of } \\
\text { Treatment- Smog Alert and Post } \\
\text { Period 2008-2010 }\end{array}$ & $\begin{array}{r}168.392 * \\
(83.892)\end{array}$ & $\begin{array}{l}-67.558 \\
(40.104)\end{array}$ & $\begin{array}{l}282.968 * \\
(130.502)\end{array}$ & $\begin{array}{l}-55.744 \\
(35.093)\end{array}$ \\
\hline $\begin{array}{l}\mathrm{R}^{2} \\
\mathrm{obs}\end{array}$ & $\begin{array}{c}0.7757 \\
172,598\end{array}$ & $\begin{array}{c}0.7559 \\
150,433\end{array}$ & $\begin{array}{l}0.7713 \\
57,535\end{array}$ & $\begin{array}{l}0.7136 \\
50,150\end{array}$ \\
\hline $\begin{array}{c}\text { Dummy-Interaction term (1 for } \\
\text { Treatment- York County and } \\
\text { Smog Alert) }\end{array}$ & $\begin{array}{c}\text { Panel B: Between } M \\
-10.600 \\
(9.221)\end{array}$ & $\begin{array}{c}\text { day-Friday_using who } \\
12.2601 \\
(11.429)\end{array}$ & $\begin{array}{l}\text { sample } \\
-21.974 \\
(20.637)\end{array}$ & $\begin{array}{c}-12.383 * * \\
(4.471)\end{array}$ \\
\hline $\begin{array}{l}\text { Dummy: } 1 \text { for Post Period 2008- } \\
\qquad 2010\end{array}$ & $\begin{array}{l}-61.689 * * \\
(25.223)\end{array}$ & $\begin{array}{l}-0.6594 \\
(0.233)\end{array}$ & $\begin{array}{l}-154.343 * * * \\
(56.232)\end{array}$ & $\begin{array}{c}2.149 * * * \\
(0.336)\end{array}$ \\
\hline
\end{tabular}




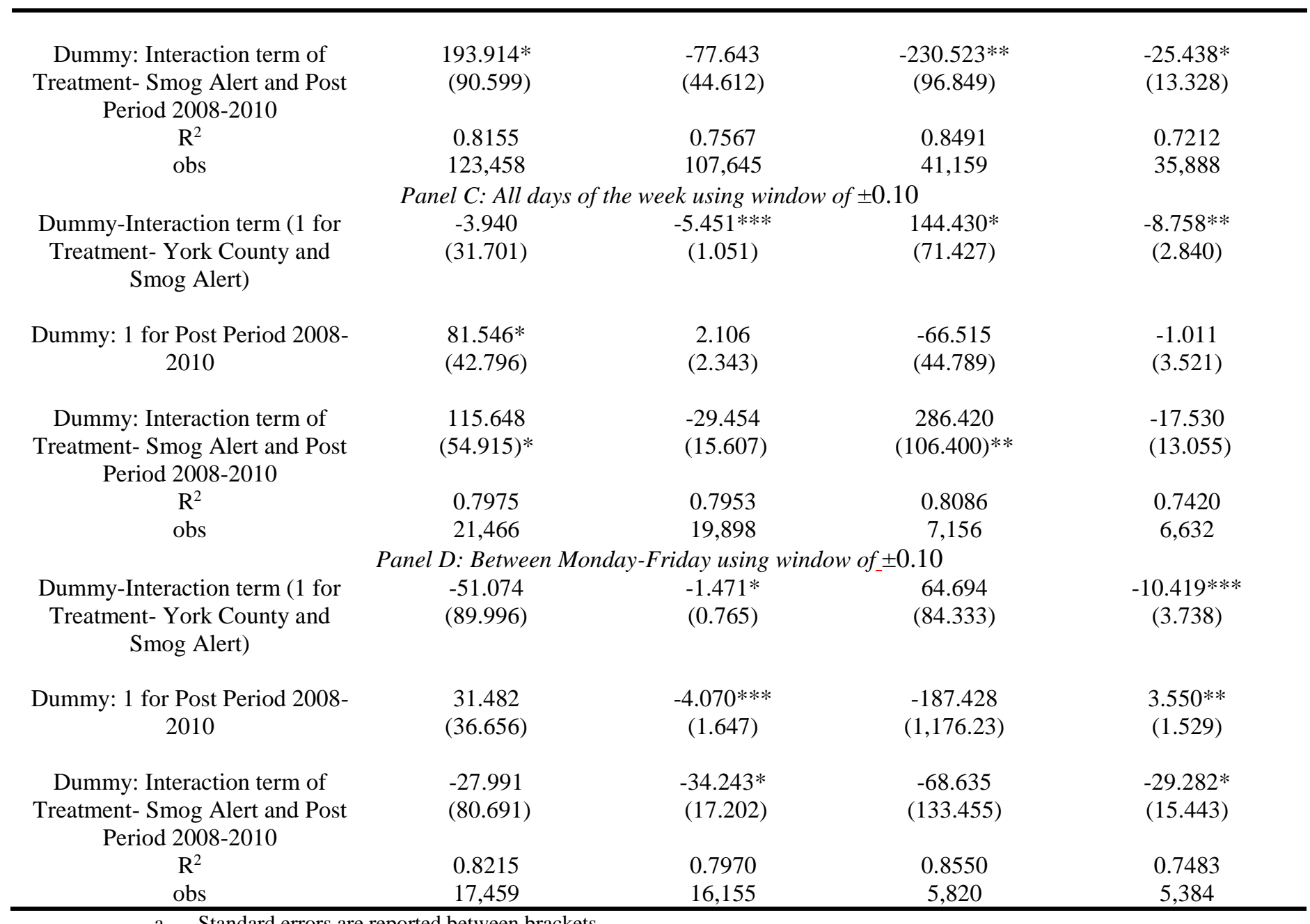

a. Standard errors are reported between brackets.

b. $\quad * * *, * *$ and $*$ denote significance at the $1 \%, 5 \%$ and $10 \%$ level

However, the traffic volume, as well as, its percentage change becomes negative, when

Mondays through Fridays are only considered, equal to -230.523 and -25.438 per cent respectively, based on panel B and columns (1)-(2).

The conclusions derived from panels $\mathrm{C}$ and $\mathrm{D}$ in table 8 , obtaining the sample using the bandwidth of \pm 0.10 are roughly the same. More specifically, the traffic volume, regarding the total hours of the day and panel $\mathrm{C}$ is positive and significant; equal to 115.648 . On the contrary, when only days Mondays-Fridays are used, the coefficient's sign of the interaction term between the smog alert issue in the treatment group and the post period becomes negative, but it is insignificant. However, there is a significant percentage decrease equal to 34.243 per cent during Mondays-Fridays. Similarly, regarding the peak hours of the day and the results of panel $\mathrm{D}$, the traffic volume is more in the treatment group by 286.420 , while the percentage change 
is negative and insignificant. On the contrary the percentage change becomes negative and significant, when only the sample of Monday-Friday is considered, equal to -29.282.

Finally in table 9 the DID model (2) is estimated, with the difference, that now the dependent variable is the actual ozone levels, controlling for the same factors. It is clear that based on the coefficient $\beta_{3}$ which is negative and significant with different bandwidths, the actual ozone concentrations are significant lower in the treatment group after the change of the threshold.

Table 9. Differences-in-Differences (DID) estimates of equation (2) and actual ozone concentrations

\begin{tabular}{|c|c|c|c|c|c|}
\hline & $(1)$ & $(2)$ & (3) & (4) & $(5)$ \\
\hline Dummy-Interaction term (1 for & -1.343 & -1.777 & -1.592 & -1.648 & -2.432 \\
\hline $\begin{array}{c}\text { Treatment- York County and Smog } \\
\text { Alert) }\end{array}$ & $(0.369)^{* * *}$ & $(1.279)$ & $(0.865)^{*}$ & $(0.314)^{* * *}$ & $(0.100)^{* * *}$ \\
\hline Dummy: 1 for Post Period 2008-2010 & $\begin{array}{c}-6.091 \\
(0.269)^{* * *}\end{array}$ & $\begin{array}{c}-5.466 \\
(0.784)^{* * *}\end{array}$ & $\begin{array}{c}-5.548 \\
(0.951)^{* * *}\end{array}$ & $\begin{array}{c}-5.814 \\
(0.428)^{* * *}\end{array}$ & $\begin{array}{c}-3.809 \\
(0.547)^{* * *}\end{array}$ \\
\hline Dummy: Interaction term of Treatment- & -3.332 & -4.838 & -4.742 & -4.386 & -5.732 \\
\hline Smog Alert and Post Period 2008-2010 & $(0.386)^{* * *}$ & $(0.731)^{* * *}$ & $(0.299)^{* * *}$ & $(0.005)^{* * *}$ & $(0.128)^{* * *}$ \\
\hline obs & 190 & 344 & 428 & 476 & 882 \\
\hline $\mathrm{R}^{2}$ & 0.8806 & 0.7964 & 0.7354 & 0.6872 & 0.5704 \\
\hline
\end{tabular}

6. Conclusions and Discussions

The idea of restricting the sample to Mondays-Fridays is the assumption that the traffic volume will be decreased or vanpool's program effects will be even stronger. This is based on the hypothesis that even if the some industries in specific sectors, like retail markets, are open even during the weekend, the factories and other firms in other industries and sectors, are closed. This can be confirmed by the results on tables 11-12. The results show a decrease of traffic volume levels only during Monday-Friday. Additionally, weekday and weekend differences in commute traffic and some industrial processes can lead to a variation in groundlevel ozone and concentrations given similar weather conditions.

Generally, based on the results, if the assumption that employees move during the most hours of the day, and especially the interval 6:00-18:00, and not only during the peak hours, is true, then the vanpooling program is not efficient before 2008, because a significant increase in 
the traffic volume is observed. Similarly, if the assumption that the employees move more frequently during the peak hours is true, which is the most reasonable case, then the vanpooling program was not efficient too before 2008, as a significant increase in traffic counts in York County is observed. However, these findings are based on the RD estimates. On the contrary, the vanpooling program has significant effects on traffic volume, during the post period 20082010 as a significant reduction of the traffic volume is observed considering the peak hours of the day and restricting the sample to Mondays-Fridays.

It seems that the change of threshold by Environmental Protection Agency has actually reduced the traffic volume in the case examined. EPA's purpose of reducing the threshold is to make individuals, companies and organizations to follow actions for reducing the pollution. Additionally, the reduction of the threshold from 0.080 to $0.075 \mathrm{ppm}$ results to more frequent warning issues and smog alerts. Therefore, one explanation is that employees in York County during period 2008-2010 take more actions after 2007, as a result of the sponsored program like the vanpooling. It can be said that individuals in both counties have the option to use public transit. This can be examined further, by using data on public transit, but because of the data unavailability, this was impossible to be done. Furthermore, individuals in all counties have the same transportation choices, but employees in York County have one more option, which is the vanpool program sponsored by CATS. This becomes clear during post period, as the traffic volume in York County is lower.

Concluding, the paper's findings are consistent with Cutter and Neidell's (2009) results concerning the period 2008-2010 and considering the peak hours of the day during MondaysFridays. Specifically, the authors examined the effects of "Spare the Air" advisory program and found significant decreases in traffic volume. At this point, it should be noticed that the current paper, as well as, Cutter and Neidell's (2009) study, examine the total volume of traffic. The drawback of these studies is that the type of the cars is not examined. One characteristic 
example is that the luxury cars pollute more. Thus, the effects of York vanpooling program or the "Spare the Air" advisory program on ozone concentrations cannot be examined and measured. Additionally, motor vehicles create sulphur dioxide emissions by burning sulphur containing fuels, especially diesel, as well as nitrogen dioxides. Then they generate additional fine particles which increase the ozone concentration levels (Harrison, 2001). On the contrary hybrid and electric cars might pollute less. Therefore, the type of the car used, might be an important factor of air pollution among others. Moreover, even if the choice of public transportation is topic of the individuals' behaviour, the results show that in Spartanburg County the individuals might probably use more frequent the public transit means, during period 2006-2007.

On the other hand the study's findings are not in line with Cummings and Walker's (2000) results, where an advisory voluntary program is examined in the Atlanta of Georgia metropolitan area on hourly traffic volumes and the authors found statistically insignificant effects.

One major question is why air quality has been improved after the change of the threshold. There might be various explanations. Firstly, EPA's purpose of reducing the threshold from 0.80 to $0.75 \mathrm{ppm}$ is to force individuals and companies to take actions in order to improve air quality. Secondly on 31 August 2007 York County has not met the 1997 ozone National Ambient Air Quality Standards. For this reason various actions and projects took place. Since March 2009 York County provides a demand response public transit service, which is a federally funded transportation assistance program. Normal operating hours are Monday through Friday from 6:00 a.m. to 6:00 p.m. and operating hours may vary depending upon capacity and passenger pick-up times. York County tries to provide the service in an efficient and cost effective manner, while serving as many residents as possible (RFATS, 2009). Therefore, this can explain the fact of a negative percentage change of traffic volume during 
Monday-Friday and considering peak hours of the day. Thirdly, in the end of 2007, the South Carolina Legislature established a statewide project priority list for all federal aid projects proposed for inclusion in the State Transportation Improvement Program (STIP). This includes various types of projects. One category is the transportation enhancement projects. Examples are the "Saluda Street Enhancements", which project is a pedestrian and streetscape improvement effort, and the "White Street Improvements", which is a landscape / hardscape project to improve pedestrian access along the White Street Corridor - which serves as an important East/West connection through the City of Rock Hill in York County. Also a major project is the "Main Street Enhancements" which proposes to extend the functionality of the existing transportation system by constructing a pedestrian / bicycle facility which will connect the downtown area with the existing facilities on Highway 160 - a major corridor- to destinations near Fort Mill High School, I-77 $^{8}$ and Baxter Village (RFATS, 2009). A second category includes Congestion Mitigation and Air Quality (CMAQ) projects. One example is the "Rail Yard Extension" which is a traffic flow improvement effort involving the construction of an additional side-track to allow trains to pull free of the Downtown grade crossing prior to switching operations. Another example is the "Clean Air Works" program which is an outreach/education project to inform city staff and the public about the importance of reducing vehicular emissions. Other examples include projects involving the addition of turning lanes to increase mobility and reduce congestion at the intersection (RFATS, 2009). The third category includes American Recovery and Reinvestment Act (ARRA) projects. The "Demand Response Program" project, which involves the acquisition of six service vehicles (Ford E-450 Starcraft Allstar Buses), is one example. It should be noted that this program is contains both an essential services component as well as an enhanced peak period (ride-to-work) option, which latter is effective since 2010. Final category includes locally funded projects, which provide additional

\footnotetext{
${ }^{8}$ Interstate 77 is an Interstate Highway between Cleveland, Ohio, and South Carolina
} 
roadway capacity and traffic operations improvement (RFATS, 2009). Generally, various research studies found that High Occupancy Vehicle (HOV) lanes might reduce vehicle-trips by encouraging more people to vanpool or carpool improving welfare, congestion and air quality (Mannering and Hamed, 1990; Small et al., 2006).

\section{Acknowledgments}

We would like to thank Smutz, Stephen from South Carolina Department of Health \& Environmental Control for providing us the ozone forecasts.

\section{References}

Abadie A, 2005, "Semiparametric difference-in-differences estimators", Review of Economic Studies 72(1) 1-19.

Air Quality Management Work Group, 2005, "Recommendations to the Clean Air Act Advisory Committee", Report to the Clean Air Act Advisory Committee.

Analitis A, Katsouyanni K, Dimakopoulou K, Samoli E, Nikoloulopoulos A K, Petasakis Y, Touloumi G, Schwartz J, Anderson HR, Cambra K, Forastiere F, Zmirou D, Vonk J M, Clancy L, Kriz B, Bobvos J, Pekkanen J, 2006, "Short-Term Effects of Ambient Particles on Cardiovascular and Respiratory Mortality,” Epidemiology 17 230-233.

Anderson H R, Atkinson R W, Peacock J L, Sweeting M J, Marston L., 2005 "Ambient Particulate Matter and Health Effects: Publication Bias in Studies of Short-Term Associations", Epidemiology 16 155-163.

Angrist J D, Pischke J S, 2008, Mostly harmless econometrics: An empiricist's companion. Princeton University Press

Bento A M, Kaffine D, Roth K, Zaragoza M, 2010, "Clearing the Air by Promoting Hybrids? The Unintended Consequences of Allowing Solo-Hybrid Drive in High Occupancy Lanes", School of Applied Economics and Management, Cornell University

Cacciola R R, Sarva M, Polosa R, 2002, “Adverse respiratory effects and allergic susceptibility in relation to particulate air pollution: flirting with disaster," Allergy $57281-286$.

Chay K Y, Greenstone M, 2003a, “Air Quality, Infant Mortality, and the Clean Air Act of 1970", NBER Working Paper No. 10053, Cambridge, MA. 
Chay K Y, Greenstone M, 2003b, "The Impact of Air Pollution on Infant Mortality: Evidence from Geographic Variation in Pollution Shocks Induced by a Recession", Quarterly Journal of Economics 118(3) 1121-1167.

Chay K Y, Dobkin C, Greenstone M, 2003, "The Clean Air Act of 1970 and Adult", Journal of Risk and Uncertainty 27(3) 279-300.

Cummings R G, Walker M B, 2000, "Measuring the effectiveness of voluntary emission reduction programmes", Applied Economics 32 1719-1726.

Currie J, Neidell M, 2005, "Air Pollution and Infant Health: What Can We Learn from California's Recent Experience?”, The Quarterly Journal of Economics 120(3) 1003-1030.

Cutter W B, Neidell M, 2009, "Voluntary information programs and environmental regulation: Evidence from 'Spare the Air", Journal of Environmental Economics and Management 58253 265.

Delfino R J, Murphy-Moulton A M, Becklake M R, 1998, "Emergency room visits for respiratory illnesses among the elderly in Montreal: association with low level ozone exposure", Environmental Research Section A 7667 - 77.

Dockery D, Pope C A, Xiping X, Spengler J, Ware J, Fay M, Ferris B, Speizer F, 1993, “An Association between Air Pollution and Mortality in Six U.S. Cities", New England Journal of Medicine 329(24) 1753-1759.

Edwards J, Walters S, Griffiths, R K, 1994, "Hospital admissions for asthma in preschool children: relationship to major roads in Birmingham, United Kingdom", Archives of Environmental Health 49 223-227.

Environmental Protection Agency, 2006, "Air Quality Criteria for Ozone and Related Photochemical Oxidants", Environmental Protection Agency, Washington DC.

Fremigacci F, 2010, "Maximum Benefits Duration and Older Workers' Transitions out of Unemployment: a Regression Discontinuity Approach", CEE Working Papers 10-12, CEE.

Friedman M S, Powell K E, Hutwagner L, Graham L M, Teague G W, 2001, "Impact of Changes in Transportation and Commuting Behaviors During the 1996 Summer Olympic Games in Atlanta on Air Quality and Childhood Asthma", Journal of the American Medical Association 285 897-905.

Hamilton J T, 1995, "Pollution as News: Media and Stock Market Reactions to the Toxics Release Inventory Data", Journal of Environmental Economics and Management 28 98-113.

Harrison R M, 2001, Pollution: Causes, Effects and Control (The Royal Society of Chemistry, UK).

Imbens G W, Lemieux T, 2008, "Regression discontinuity designs: A guide to practice", Journal of Econometrics 142(2) 615-635. 
Imbens G, Kalyanaraman K, 2009, "Optimal Bandwidth Choice for the Regression Discontinuity Estimator", NBER Working Papers 14726, National Bureau of Economic Research.

Ishizaki T, Koizumi K, Ikemori R, Ishiyama Y, Kushibiki E, 1987, "Studies of prevalence of Japanese cedar pollinosis among the residents in a densely cultivated area", Ann Allergy $\mathbf{5 8}$ 265-270.

Janssen N A H, Schwartz J, Zanobetti A, Suh H H, 2002, "Air conditioning and source-specific particles as modifiers of the effect of PM10 on hospital admissions for heart and lung disease", Environmental Health Perspectives 11043 - 49.

Konar S, Cohen M A, 1997, "Information as regulation: the effect of community right to know laws on toxic emissions", Journal of Environmental Economics and Management 32 109-124.

Laden F, Neas L M, Dockery D W, Schwartz J, 2000, “Association of fine particulate matter from different sources with daily mortality in six US cities", Environmental Health Perspectives 108941 - 947.

Lancaster County Planning Commission Staff for the Lancaster County Transportation Coordinating Committee, 2012, "Air Quality Conformity Analysis Report for the Lancaster County 8-hour Ozone Maintenance Area and Annual and 24-hour PM2.5 Nonattainment Area”, Lancaster County.

Lee D, Lemieux T, 2010, "Regression Discontinuity Designs in Economics", Journal of Economic Literature, American Economic Association 48(2) 281-355.

Lu J, Weir J, Schreffler E N, McLarney T, Sarles R, Higgins T, Johnson W, 2007, "Development of Quantification Method for Measuring Travel and Emissions Impacts of Episodic Ozone Alert Programs", Transportation Research Record: Journal of the Transportation Research Board 1864 153-159.

Mannering F, Hamed M, 1990, "Commuter Welfare Approach to High Occupancy Vehicle Lane Evaluation: An Exploratory Analysis", Transportation Research A(24) 371-379.

McConnell R, Berhane K, Yao L, Jerrett M, Et al, 2006, “Traffic, Susceptibility, and Childhood Asthma", Archives of Environmental Health 114(5) 766-772.

Naeher L P, Holford T R, Beckett W S, Belanger K, Triche E W, Bracken M B, et al, 1999, "Healthy Women's PEF Variations with Ambient Summer Concentrations of $\mathrm{PM}_{10}, \mathrm{PM}_{2.5}, \mathrm{SO}_{4}$ ${ }^{2}, \mathrm{H}^{+}$, and $\mathrm{O}_{3} "$, American Journal of Respiratory Critical Care Medicine 160 117-125.

O’Neill M S, Loomis D, Borja-Aburto V H, 2004, “Ozone, area social conditions, and mortality in Mexico City”, Environmental Research 94 234-242.

Ono M, Murakami M, Nitta H, Nakai S, Maeda K, 1990, "Epidemiological studies of air pollution and health effects in areas near roadways with heavy traffic in Tokyo", Nippon Koshu Eisei Zasshi 37 321-332. 
Oosterlee A, Drijver M, Lebret E, Brunekreef B, 1996, "Chronic respiratory symptoms in children and adults living along streets with high traffic density", Occupation and Environmental Medicine 53 241-247.

Ostro B, Broadwin R, Green S, Feng W Y, Lipsett M, 2006, "Fine Particulate Air Pollution and Mortality in Nine California Counties: Results from CALFINE", Environmental Health Perspectives 114 29-33.

Preutthipan A, Udomsubpayakul U, Chaisupamongkollarp T, Pentamwa P, 2004, "Effect of PM10 pollution in Bangkok on Children with and without asthma", Pediatric Pulmonology 37 $187-192$.

Reading Metropolitan Planning Organization and Pennsylvania Department of Transportation, 2010, "Air Quality Conformity Analysis Report for the Reading Ozone and 24-hour PM2.5 Nonattainment Area", Reading County.

RFATS, 2009, “FY 2009-2015: Transportation Improvement Program (TIP)”, Rock Hill-Fort Mill Area Transportation Study.

Schreffler E, 2003, "Quantification methods for identifying emission reductions resulting from seasonal and episodic public education programs", Air Resource Board Final Research Report.

Sexton S E, 2010, "Rationing Public Goods by Cooperation or Pecuniary Incentives: Evidence from the Spare-the-Air Program", CUDARE Working Paper No. 1107, Department of Agricultural and Resource Economics, UCB, UC Berkeley.

Shima M, Nitta Y, Ando M, Adachi M, 2002, "Effects of Air Pollution on the Prevalence and Incidence of Asthma in Children", Archives of Environmental Health 57 529-535.

Shima M, Nitta Y, Adachi M, 2003, "Traffic-related air pollution and respiratory symptoms in children living along trunk roads in Chiba Prefecture, Japan", Journal of Epidemiology 13(2) $108-119$.

Small K, Winston C, Yan J, 2006, "Differentiated Road Pricing, Express Lanes and Carpools: Exploiting Heterogeneous Preferences in Policy Design", Unpublished Working Paper 06-0602, AEI-Brookings Joint Center for Regulatory Studies.

Suresh Y, Sailaja Devi M M, Manjari V, Das U N, 2000, “Oxidant stress, antioxidants, and nitric oxide in traffic police of Hyderabad, India", Environmental Pollution 109321 - 325.

Thistlethwaite D L, Campbell D T, 1960, "Regression-Discontinuity Analysis: An alternative to the ex post facto experiment", Journal of Educational Psychology 51(6) 309-317.

United Nations, 1989, "Prospects of world urbanization", Population studies no. 112, New Rock Hill-York.

United Nations, 2012, "World Urbanization Prospects: The 2011 Revision", Department of Economic and Social Affairs, New Rock Hill-York. 
Yokoyama Y, Nitta H, Maeda K, Aoki S, 1985, "What interaction does indoor nitrogen dioxide have on the effect of the automobile exhaust", Tokai journal of experimental and clinical medicine 10 379-384.

Van Vliet P, Knape M, De Hartog J, Janssen N, Hassema H, Brunekreef B, 1997, "Motor vehicle exhaust and chronic respiratory symptoms in children living near freeways", Environmental Research 74 122-132.

Welch E, Gu X, Kramer L, 2005, "The effects of ozone action day public advisories on train ridership in Chicago", Transportation Research Part D: Transport and Environment 10445 458.

Wilhelm M, Ritz B, 2003, "Residential proximity to traffic and adverse birth outcomes in Los Angeles County, California, 1994 - 1996”, Environmental Health Perspectives 111207 - 216.

Map 1. South Carolina Ozone Monitoring Network Map 1:500,000

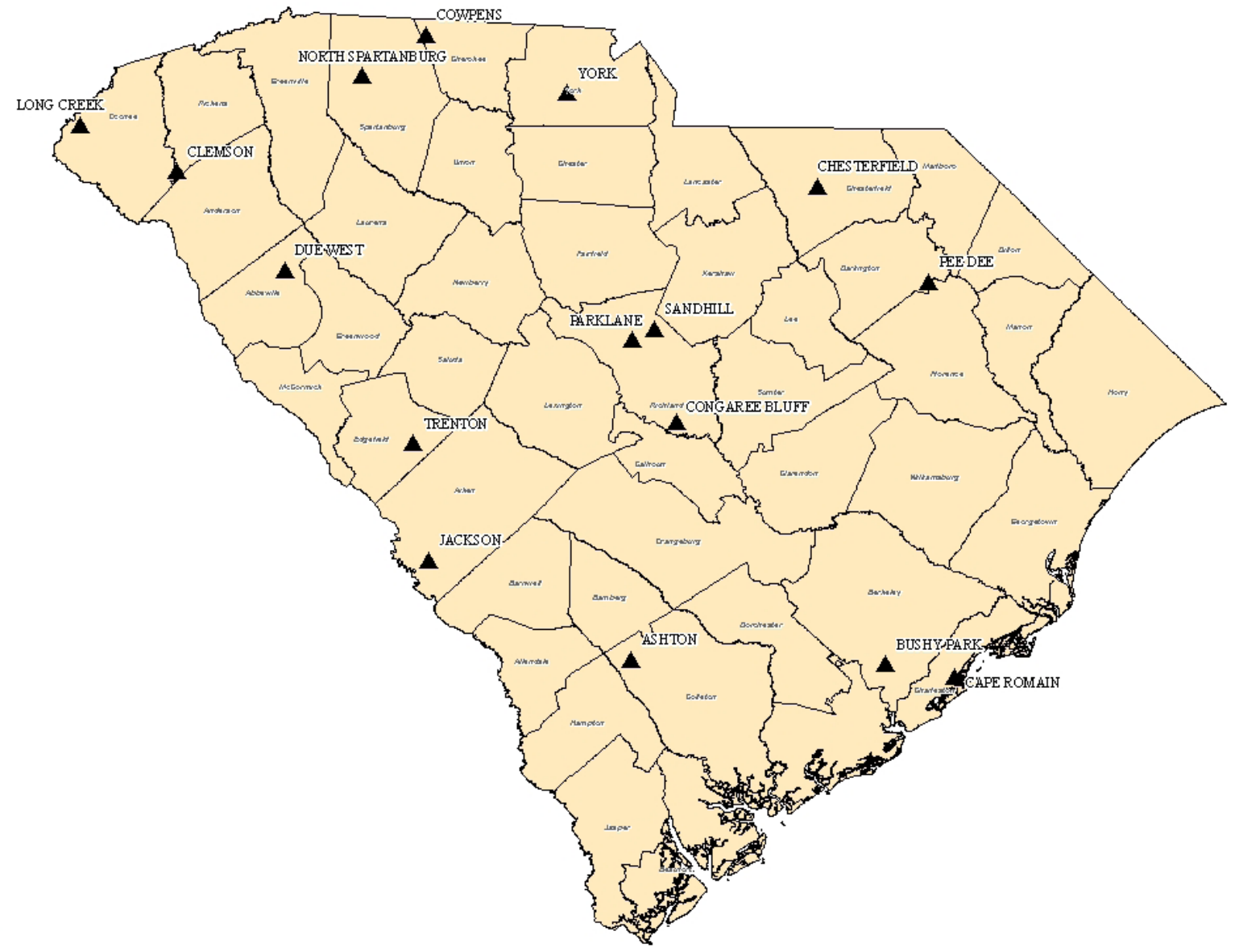


Figure 1. Histogram for traffic volume during period 2006-2007 in York County

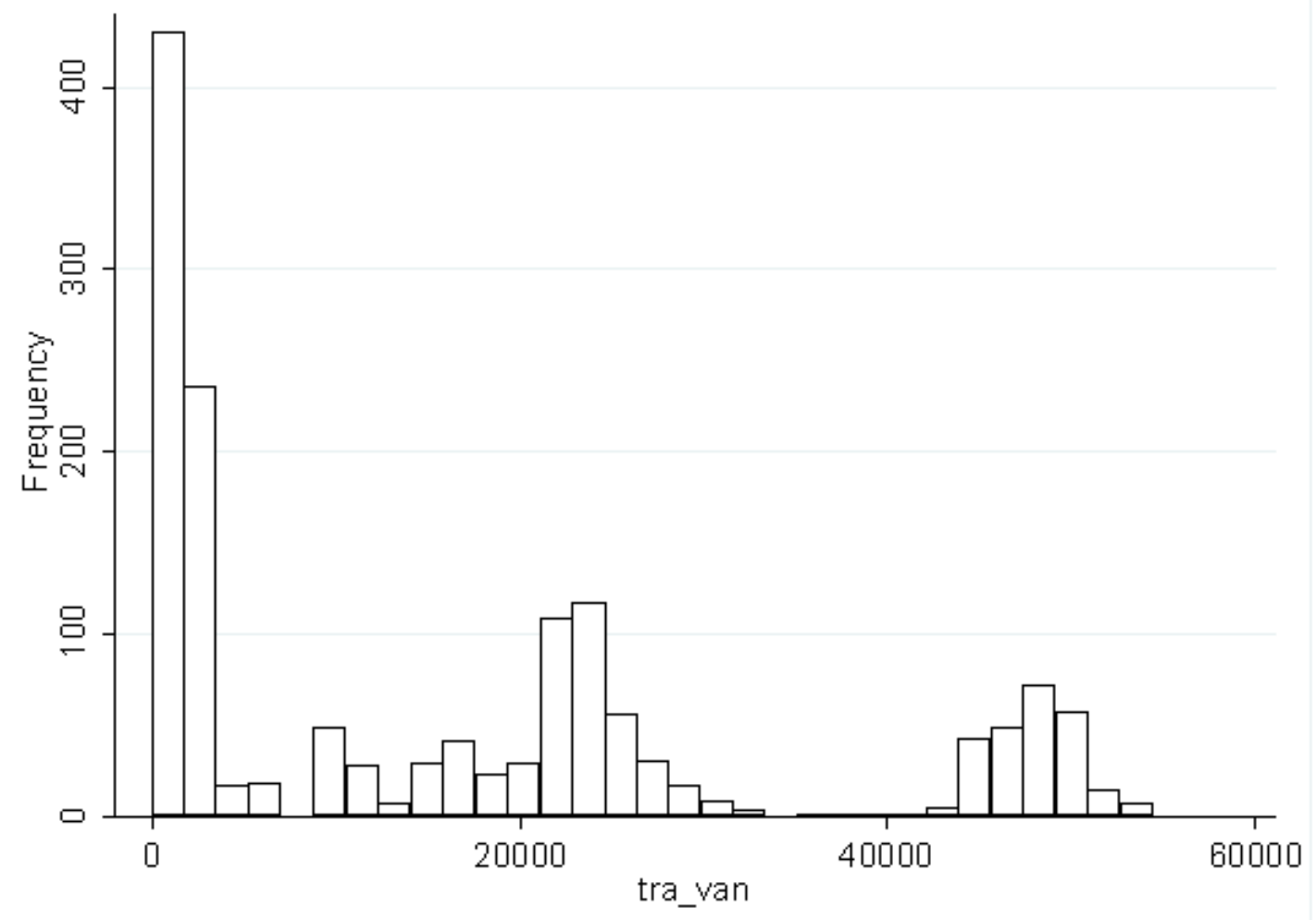

Figure 2. Histogram for traffic volume during period 2006-2007 in Spartanburg County 


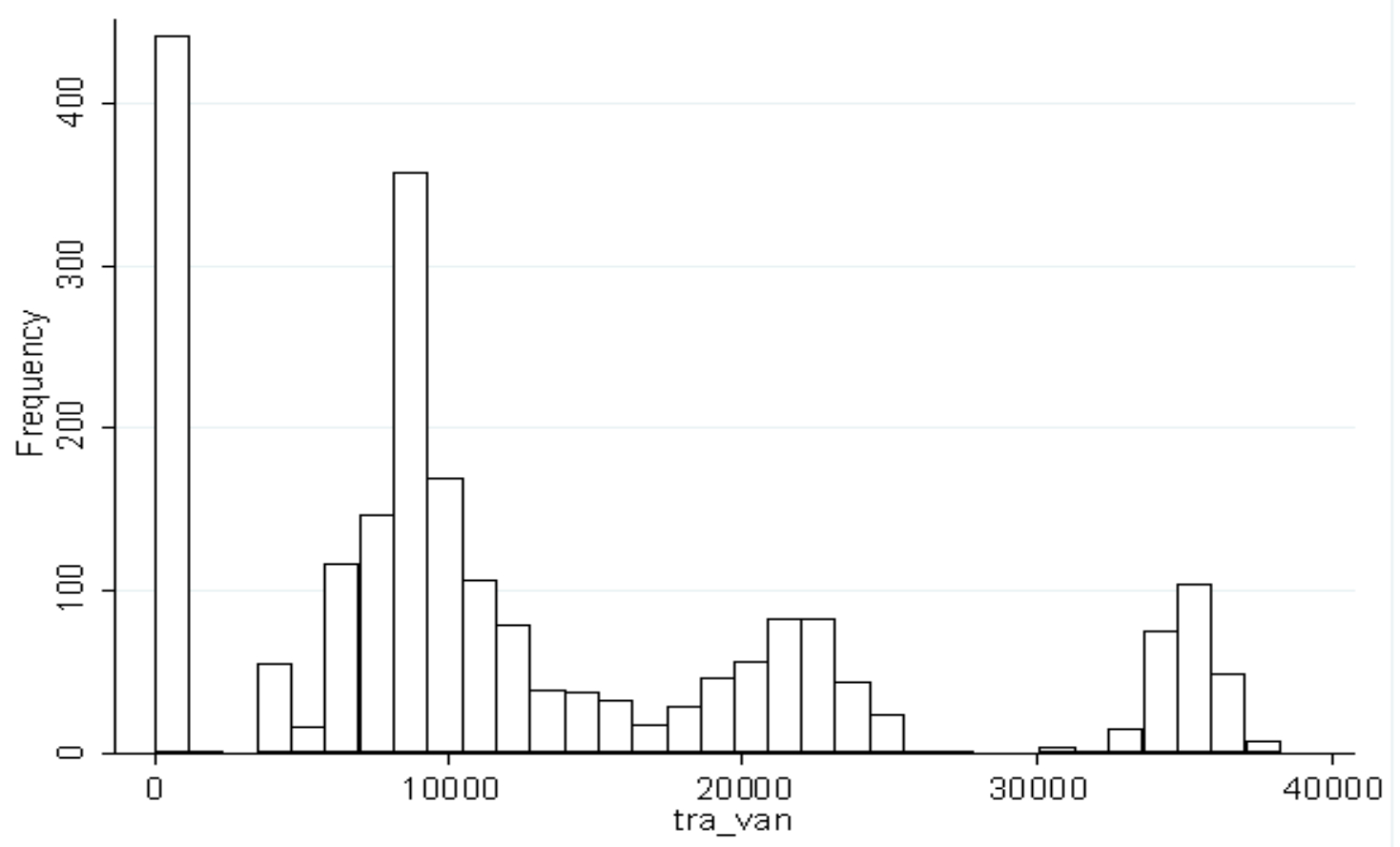

Figure 3. Histogram for traffic volume during period 2008-2010 in York County

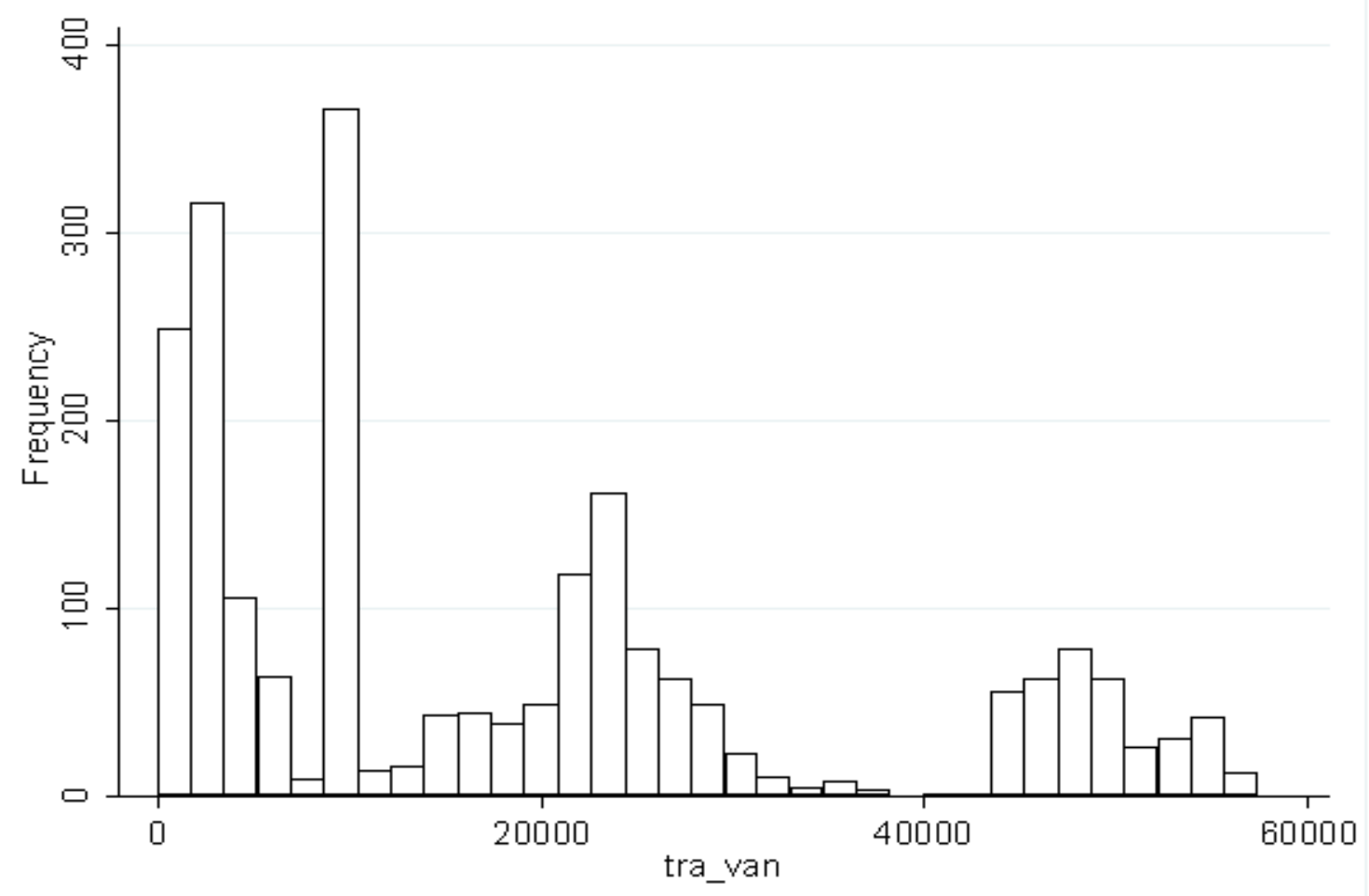

Figure 4. Histogram for traffic volume during period 2008-2010 in Spartanburg County 


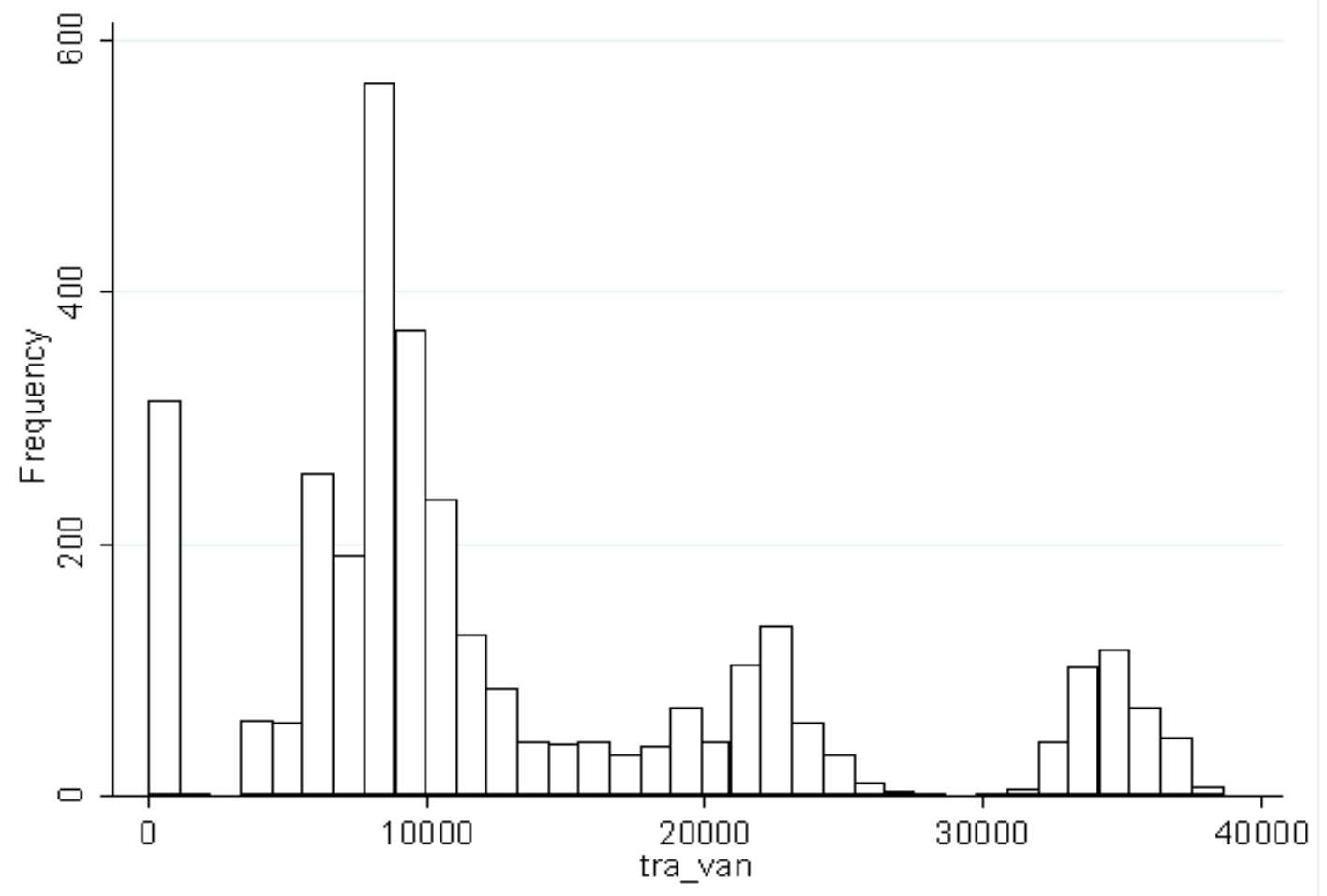

Figure 5. Differences-in-Differences (DID) - Regression Discontinuity Design (RDD) estimates for equation (1) for the total hours of the day using a window of \pm 0.10 during period 2008-2010

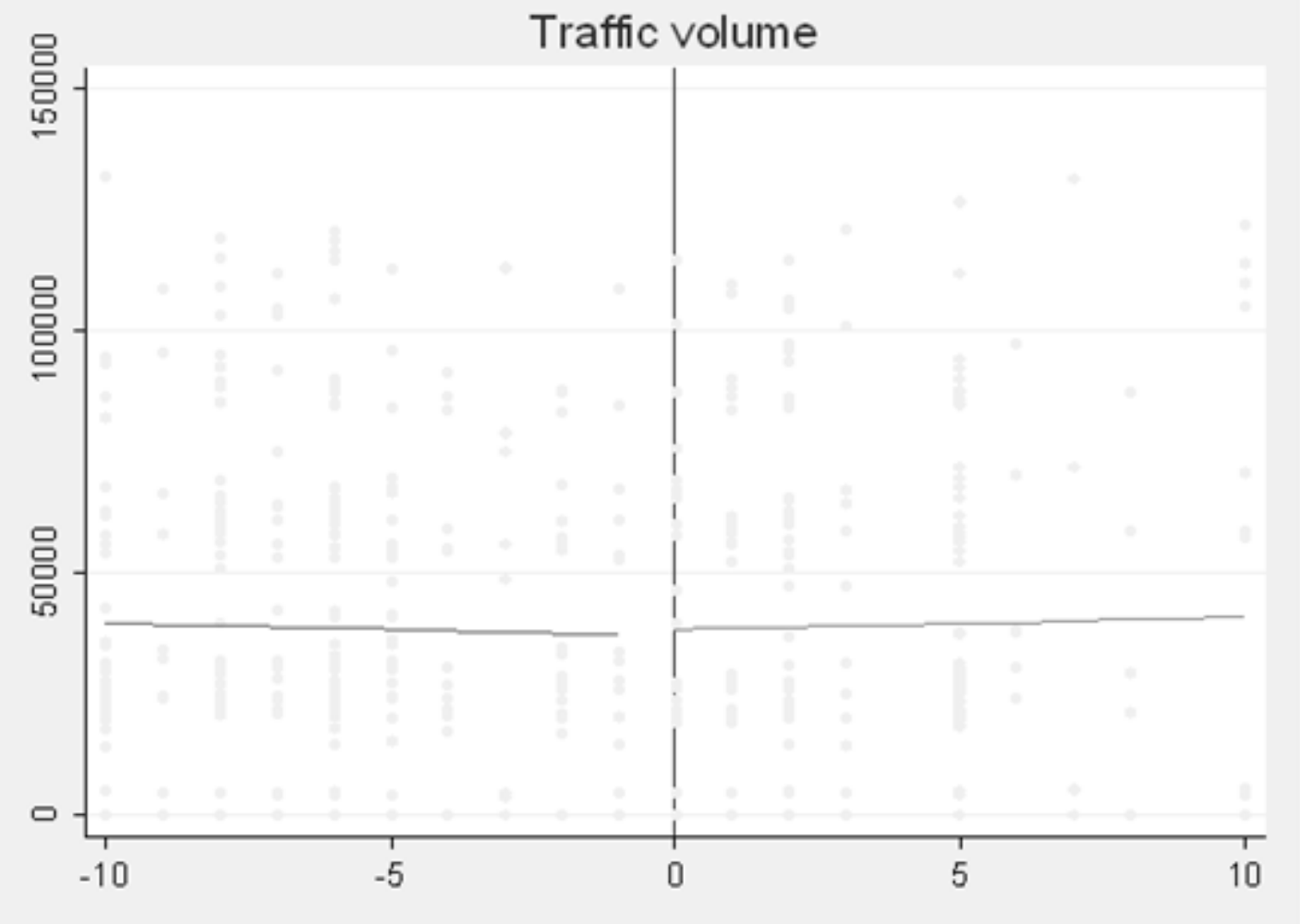


Figure 6. Differences-in-Differences (DID) - Regression Discontinuity Design (RDD) estimates for equation (1) for the peak hours of the day using a window of \pm 0.10 during period 2008-2010

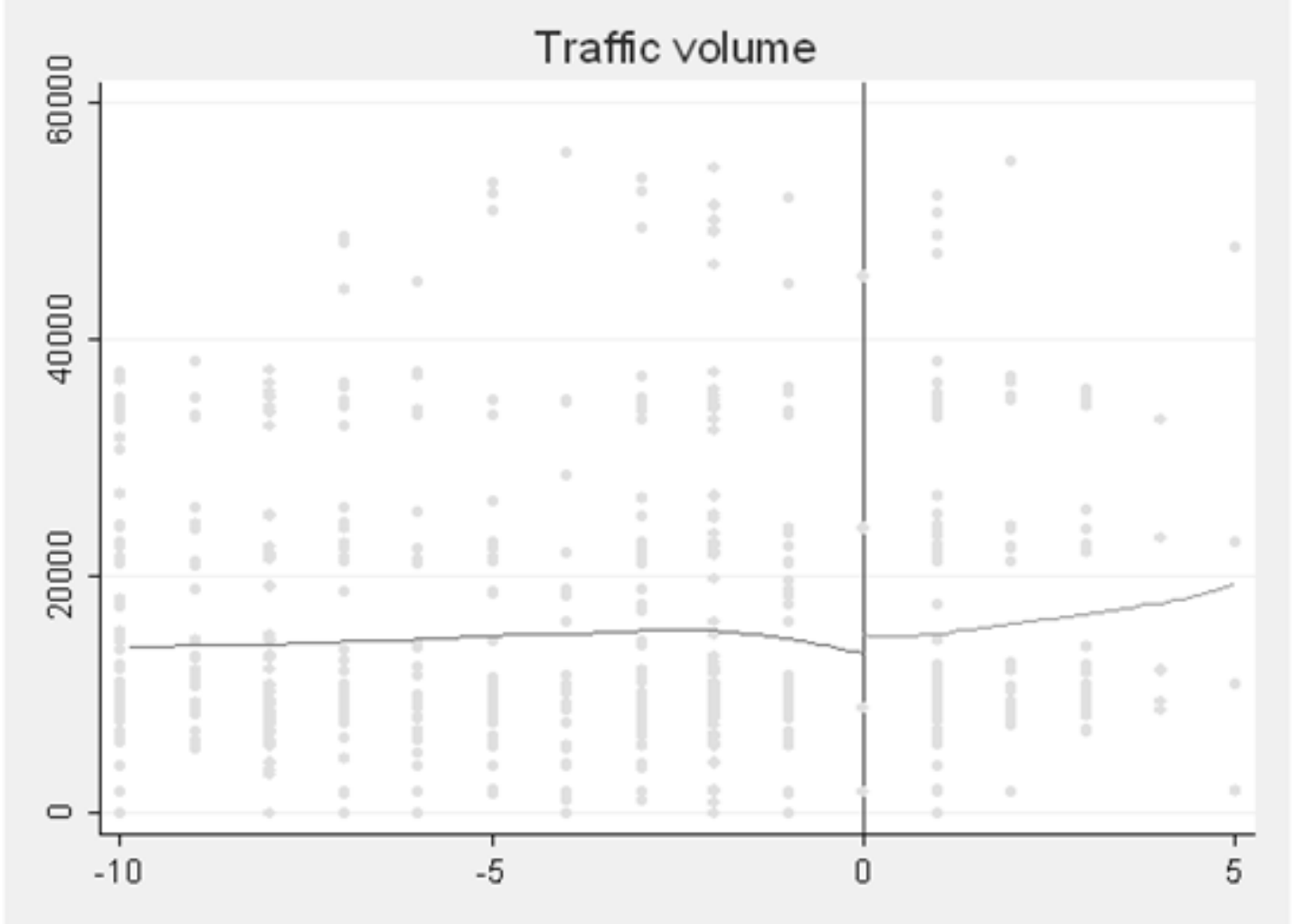

